\title{
EN BOK, EN BLOGG OG EN BLONDINE. PERSONLIG POLITISK LEDERSKAP I NYE MEDIER
}

Published in Sosiologisk Tidsskrift (2007), Vol. 15: 195-225

Anne Krogstad, Institute for Social Research anne.krogstad@sosiologi.uio.no

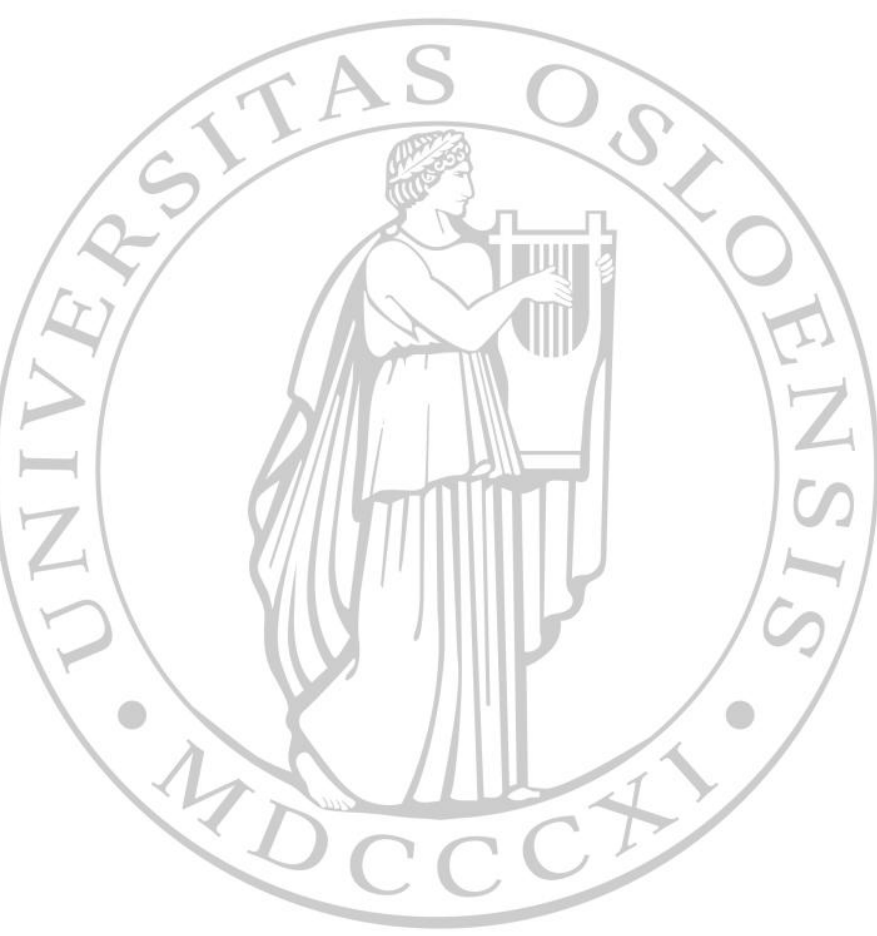

Department of Sociology and Human Geography University of Oslo

P.O.Box 1096 Blindern

N-0317 OSLO Norway

Telephone: $\quad+4722855257$

Fax:

$+4722855253$

Internet: http://www.iss.uio.no 


\section{EN BOK, EN BLOGG OG EN BLONDINE. PERSONLIG POLITISK LEDERSKAP I NYE MEDIER}

Anne Krogstad

anne.krogstad@sosiologi.uio.no

\section{A book, a blog and a blonde. Personalized political leadership in new media}

The leader of the Socialist Left Party, Kristin Halvorsen, is regarded as one of Norway's most sophisticated politicians when it comes to projecting personality in her verbal and visual messages, both face-to-face and on television. But why and how does she convey personality through the fingertips, computer keyboards and PC screens in media where verbal and visual expressions are virtually replaced by text? The point of departure for the article is a triple Internet launch initiated by Halvorsen: a combined book and web site, a blog and two web meetings. So far, Halvorsen's web engagement has been one of the most systematic and comprehensive attempts in Norway to use the Internet to create new and more direct forms of political participation. In this article, her web communication is studied for the period October 2004 until the Parliamentary election in September 2005. The theoretical point of departure is charisma, or its more subtle equivalents, charm, impression management and frontstage and backstage presentations, which are combined and developed within a concept of middle scene presentation. In her presentations, Halvorsen creates a stage on which she demonstrates a closeness to voters, an appealing personality and leadership. The combined book and web site, the blog and the web meetings are compared with reference to Halvorsen's (and the party's) purpose of communication, her personal-political presentation and style of communication. The response to the three forms of communication is analysed with reference to the degree of response, frequency, interactivity, style, content and gender. There are two main conclusions: the first, that even though personalized web communication is regularly seen as informal and spontaneous, a party leader has to remember that it is in fact formal and public. Nevertheless, the impression that comes over is that Halvorsen's combined book and web site come "straight from the heart», the blog "straight from the liver» and that people's comments in web meetings go "straight into Halvorsen's ear». The second conclusion is that her middle scene presentation on the web was politically sustainable in the first part of the election campaign, but that the results were meagre compared to efforts in the intense last part of the campaign, when more established media were given priority.

Key words: Kristin Halvorsen, Internet, Web communication, Blog, Interactivity, Middle scene presentation. 


\section{Hvordan formidle personlig politisk lederskap gjennom fingertupper, tastatur og pc-skjerm? ${ }^{\prime}$}

SVs leder, Kristin Halvorsen regnes gjerne som en av landets fremste politikere når det gjelder å projisere personlighet inn i sine verbale og visuelle budskap, både ansikt til ansikt og i fjernsynskommunikasjon (Krogstad, 2004a; Ukeavisen Ledelse, 19.08.05). Men hvordan formidler hun personlig lederskap gjennom fingertupper, tastatur og pc-skjerm? Mens de fleste forskere har studert slikt lederskap i direkte møter eller i fjernsynssammenheng, knyttes spørsmålet her til hvorfor, hvordan og med hvilken oppslutning Halvorsens personlig politiske lederskap iscenesettes i nye, interaktive medier, medier der mye av det visuelle og verbale er erstattet av tekst.

Det er ikke så uvanlig at forhenværende norske politikere gir ut bok. Mer uvanlig er det at de gir ut bok i kombinasjon med egen hjemmeside. Og helt uvanlig var det - inntil 2004 - at denne hjemmesiden inkluderte en blogg, en omvendt kronologisk, personlig nettdagbok med linker til andre sider og med oppfordringer til folk om å gi kommentarer og innspill. Kristin Halvorsen var den første norske partileder som opprettet egen blogg. Anledningen var utgivelsen av Halvorsens bok Rett fra hjertet, som kom den 26. oktober 2004. Ifølge Halvorsen var boka mer et utgangspunkt for dialog enn en ferdig tekst. Det bevisst uferdige ved boka ble understreket ved at den ikke hadde fotnoter eller kildehenvisninger. Disse var lagt ut på hjemmesiden www.svkristin.no. Også diskusjonene rundt boka var en løpende sak på hjemmesiden. I tillegg hadde hjemmesiden både blogg og nettmøter.

Hjemmesider, blogger og nettmøter fremholdes gjerne som nye medier. Nå er det litt uklart hva forskjellen mellom nye og gamle medier består i. Men enkelte påpeker at dette kan være første gang i historien at vanlige mennesker tilnæermet sensurfritt og deskfritt kan skrive hva de vil i en bredere offentlighet (Rasmussen, 2003a). ${ }^{2}$ For eksempel sies blogging å fungere som en kontroll- og debattinstitusjon som kan viderebringe mangfold i de offentlige debattene (Observer Norge/Mandag Morgen, 22.08.05). Blogging sies videre å representere "en femte statsmakt», et korrektiv til de andre statsmaktene, sæerlig den fjerde pressen. ${ }^{3}$ Ifølge Observer Norge kan bloggosfæren, som fellesskapet av blogger gjerne kalles, ikke lenger bare omtales som fenomen, men som en kraft og en ny og viktig samfunnsarena. ${ }^{4}$

I forhold til temaet nettpolitikk er Halvorsens nettinitiativ valgt av strategisk hensyn: Initiativet er ett av de mest gjennomtenkte forsøkene på å drive nettdemokrati i Norge. I artikkelen studeres Halvorsens personlig politiske kommunikasjon i den kombinerte bok og hjemmesiden, i bloggen og i to nettmøter. Jeg benytter tre innfallsvinkler: Halvorsens (og partiets) mål med kommunika- 
sjonen, hennes personlig politiske profilering og hennes retoriske stil og virkemidler. Jeg vil også undersøke responsen på Halvorsens nettutspill - med hensyn til omfang, frekvens, interaktivitet, innhold og kjønnsfordeling. Gjennom bruk av en kombinert kvalitativ og kvantitativ metode er målet å kunne sammenlikne de kommunikative former og fellesskap som skapes mellom partileder og potensielle velgere i den kombinerte bok/hjemmesiden, i bloggen og i nettmøtene.

Studien har tre metodiske hovedinntak. For det første er den basert på halvstrukturerte intervjuer og samtaler med sentrale SV-ere høsten 2004 og våren 2005 om forholdet til medier og bruk av informasjons- og kommunikasjonsteknologi. Disse intervjuene sier noe om hvilke hensikter partiledelsen har hatt med innføringen av nye interaktive medier. Det er også foretatt halvstrukturerte intervjuer om samme tema med alle partiene på Stortinget i samme periode, noe som gir et visst sammenlikningsgrunnlag for studien av SV. ${ }^{5}$

For det andre er studien basert på innholdsanalyser av 1) Halvorsens kombinerte bok og hjemmeside, 2) Halvorsens 40 bloggpostinger i perioden 26. oktober 2004 til 10. juni 2005, da Halvorsen nedla bloggen og 3) to nettmøter arrangert av Halvorsen på egen hjemmeside henholdsvis 9. november og 15. desember 2004, der hun svarte på 99 nettmøtespørsmål. Innholdsanalysene sier noe om mål, profilering og virkemidler i Halvorsens kommunikasjon.

For det tredje er studien basert på innholdsanalyser av 1) responsen på Halvorsens bok/hjemmeside, som omfatter 21 avisanmeldelser og 23 nettkommentarer, 2) responsen på Halvorsens blogg, nærmere bestemt 549 kommentarer og 3) 99 nettmøtespørsmål stilt til Halvorsen. Responsen er undersøkt fordi appell, evnen til å skape oppslutning, og helst begeistring, er en sentral del av et personlig politisk lederskap. Dette tas opp i neste del.

\section{Karisma, inntrykkskontroll og midtsceneprofilering}

Et klassisk utgangspunkt for studier av personlig politisk lederskap er Max Webers arbeider om karisma (1968 [1922]). Disse arbeidene er i artikkelen utdypet med Erving Goffmans begrep inntrykkskontroll, som spesielt knyttes til front- og backstage-presentasjoner (Goffman, 1963, 1992 [1959]), og med Joshua Meyrowitz' (1985) begrep «midtsted» eller, som jeg selv vil kalle det, midtsceneprofilering. Begrepet midtsceneprofilering drøftes og videreutvikles i forhold til Halvorsens personifiserte politiske kommunikasjon, en kommunikasjon der likhets- og nærhetsorienteringen i det norske politiske offentlighetsidealet bringes inn på nye arenaer, på nye måter.

Ifølge Weber (1968) er «karismatisk» autoritet en annen form for autoritet enn den som ligger i «tradisjonell» og «legal-rasjonell» autoritet. Karismatisk 
autoritet er personlig, ikke nedarvet eller posisjonsbestemt. Den har to hovedtrekk, personlig tiltrekningskraft og forandring eller fornyelse, og er basert på "the devotion to the exceptional sanctity, heroism or exemplary character of an individual person, and of the normative patterns or order revealed or ordained by him» (Weber, 1968:46). Den karismatiske leder tillegges eksepsjonelle kvaliteter og er således «set apart from ordinary men" (Weber, 1968:48).

Nå kan man innvende at norske politikere snarere kan ses som ukarismatiske og uspennende, preget av fornuft og jordnærhet, sammenliknet med den eksepsjonelle og endringsorienterte helten Weber omtaler i sine karismastudier. Det Weber betegner som "ordinary men", ikke de ekstraordinære, vil være de lederne som gjerne har størst legitimitet (Krogstad og Storvik, 2007). Demonstrasjon av høy sosial og politisk status vil stort sett virke fremmed i norsk politisk kultur. Norske velgere er også skeptiske til klassisk dannelse, til elegant retorikk og velplissert tale. Stilt overfor dilemmaet mellom likhet og ulikhet og mellom nærhet og distanse i forhold til velgerne, et dilemma enhver politisk leder vil oppleve, har norske politikere først og fremst orientert seg mot likhet og nærhet. Denne orienteringen er det historiske årsaker til. Ifølge Erik Henningsen og Halvard Vike (1999) er den politiske eliten i Norge trolig unik i den forstand at den er formet av særdeles vellykkede folkelige mobiliseringer. Det trauste, fantasiløse og antielitistiske offentlighetsidealet kan ses som et resultat av en norsk - og til dels nordisk - moderniseringsprosess som skiller seg ut fra Europa for øvrig. I denne prosessen har likhetstanken, som egenskap ved lokalsamfunnets livsverden, gjennomsyret den politiske offentligheten. Det er mange flere som har deltatt i utformingen av den politiske offentligheten i Norge enn i de fleste andre vestlige demokratier (Henningsen og Vike, 1999). Likhet er et gjennomgående motiv, et kulturelt dreiepunkt, som rommer atskillig retorisk kraft (Lien, Vike og Lidén, 2001). Ikke minst på det politiske feltet, der en politiker er avhengig av velgernes oppslutning, er det viktig å demonstrere nærhet til velgerne og å fremstå som kledelig beskjeden og tilbakelent samtidig med utøvelsen av lederskap. Henningsen og Vike (1999) kaller det folkelig elitisme. Jean-Pascal Daloz (2007) kaller det, med bakgrunn i sammenliknende studier, "conspicuous modesty", iøynefallende beskjedenhet. Det politiske lederskapsidealet er ikke først og fremst den sterke og heroiske leder, men den antiautoritære, fellesskapsorienterte "folkets tjener».

Kanskje er sjarm et bedre uttrykk enn det noe pretensiøse begrepet karisma når man skal prøve å si noe om norske politikeres personlige lederskap? Mens karisma ofte inngår i asymmetriske autoritetsforhold, kan sjarmen vel så gjerne spilles ut i symmetriske forhold, som en nesten kameratslig form for lederskap. Da Jens Stoltenberg ble partileder i Arbeiderpartiet, ble han for eksempel omtalt som "en sjarmør med maktvegring» (Dagbladet, 27.12.05). I mindre 
kjente deler av sitt forfatterskap åpner faktisk Weber for en slik symmetrisk, antiautoritær form for karismatisk lederskap (Weber 1968:53). Antakelig vil denne folkelige karismaen best dekke norsk politisk lederskap.

Mens Webers karismabegrep ble utviklet på grunnlag av situasjoner der ledere og tilhengere var i hverandres fysiske nærhet, i ansikt-til-ansikt-forhold, er fokuset her et annet: på hvordan en toppolitiker fremtrer og kommuniserer på arenaer der nettmedier legger premisser for kommunikasjonen. Det er ikke gitt at en politiker som tillegges ansikt-til-ansikt-karisma eller, for den saks skyld, fjernsynstekke, også tillegges nett-tekke. I nettsammenheng er det først og fremst tekst, ikke utseende og tale som står i fokus. Akkurat slik den førelektroniske, høyrøstede politikerstilen med store gester ikke var egnet på fjernsyn, vil fjernsynspolitikernes konverserende og relativt dannede stil ikke umiddelbart kunne konverteres til nettmedienes spontane lavstil (Sandnes, 2004). Og mens ansikt-til-ansikt-kommunikasjon i prinsippet kan omfatte alle sanser, vil sanserepertoarene som inngår i nettkommunikasjon være mer begrenset. Her er det ingen utveksling av blikk, lyd/stemme, berøring eller pust - tegn som i ulike kombinasjoner vanligvis preger menneskelig samhandling (Kummervold, 1998).

Når jeg likevel ønsker å benytte Goffman (1963, 1992), som skrev sine hovedverk før nettmedienes inntreden, kan det kanskje virke litt søkt. Men Goffmans begrep om inntrykksstyring vil kunne supplere teorien om personlig politisk lederskap, også i nye medier: Ved hjelp av begrepet inntrykksstyring lager Goffman nitide næranalyser av hvordan folk iscenesetter og styrer inntrykkene av seg selv i sosiale møter. Også hans begreper om front- og backstage-presentasjoner gir innsikt, ikke minst i politikeres pendling mellom åpne og skjulte sider ved deres opptredener. Dette begrepsparet vil blant annet utdype det arenaspesifikke ved et personlig politisk lederskap.

Joshua Meyrowitz (1985) tar Goffmans begrepspar et skritt videre idet han hevder at moderne medier skaper et "mellom-» eller "midtsted». Bakscenen, det personlige og private ved en politiker, er blitt stadig mer eksponert i offentligheten. ${ }^{6}$ Elementer fra bakscenen lanseres på forscenen, hevder Meyrowitz. Dette eksemplifiseres ved den posisjoneringen politikere og andre foretar når de står overfor ulike typer publikum: de gjør litt av hvert, de er både intime og offentlige. Meyrowitz' bidrag er at han spesifiserer hvordan den situasjonsbestemte "geografien", utviskingen av grenseflatene mellom scenekant og bakrom, forandres med introduksjonen av moderne medier. Forholdet mellom fysisk setting og sosial situasjon endres. Ifølge Martin Eide (2001) kan slike sceneendringer få konsekvenser for politikerrollen, for den politiske retorikk og for politikerens handlingsrom. Politikerne må bedrive mest mulig profesjonell og kontrollert inntrykkshåndtering i et område som ligger bakenfor gamle 
dagers forscene, men samtidig foran det som fortsatt finnes og må bevares av den innerste delen av bakscenen («deep backstage») (Gripsrud, 2002). De må med andre ord finne frem til en best mulig "midtsceneatferd» eller, som jeg har valgt å kalle det, siden det dreier seg om strategisk iscenesettelse, midtsceneprofilering. På denne brede, kompromissaktige catch all-scenen profilerer politikere seg med en blandingsatferd: Først og fremst posisjonerer de seg som like og nære, men siden de er ledere, må de også bevare en viss ulikhet og distanse, noe som gjør det mulig for dem å meisle ut et personlig politisk lederskap uten å bikke over i det helt private. Jeg vil påstå at denne midtsceneprofileringen er vel så tilgjengelig for kvinner som for menn. Kvinner knyttes gjerne til personog erfaringsorientert kommunikasjon, i alle fall stereotypisk. Og, vil jeg videre påstå, den passer som hånd i hanske til de interaktive medienes kommunikasjonsform, selv uten press fra personorienterte journalister. Faren er imidlertid at flyttingen eller utviskingen av grensen mellom den offentlige scenen og den private bakscenen fører til tap av kontroll.

\section{SV: åpen, moderne kommunikasjon}

Det er ikke foretatt særlig mange studier av norske partiers bruk av ny kommunikasjonsteknologi - av en viss grunn. Hestviks analyse av valgkampen i 2001 viser at elektroniske medier bare utgjorde en marginal, direkte kommunikasjonskanal mellom partier og velgere, til tross for store forventninger til disse mediene (Hestvik, 2004). Elektroniske medier har riktignok spilt en rolle i partienes indre liv (Heidar og Saglie, 2002), ikke minst på topp- og middelnivå (Pedersen og Saglie, 2005; Saglie, 2007). Men de har så langt hatt beskjeden virkning på partienes oppslutning og utadrettede kommunikasjon. Også studier av USA, Storbritannia og en rekke andre europeiske land, inkludert Danmark, støtter cyberskeptikerne når det gjelder partiers og velgeres forsøk å komme «rundt» massemedienes enveiskommunikasjon (Gibson, Margolis, Resnick og Ward, 2003; Norris, 2001; Löfgren, 2001; Pedersen og Saglie, 2005).

Det demokratiske potensialet er likevel fullt ut til stede, «men da må man også være villig til å bruke både den tiden og de ressursene som kreves», hevder Hestvik (2004:249). I opptakten til stortingsvalget 2005 satset SV og Kristin Halvorsen hardt på denne muligheten, dette i et land som i europeisk sammenheng ligger blant de fremste når det gjelder tilgang til internett (Grönlund, 2004; Karlsen, Aardal og Christensen, 2005). Tom Nørbech, SVs daværende web-ansvarlige, som ut over det rent tekniske også hadde ansvar for strategiske spørsmål i forbindelse med partiets bruk av internett, hevdet i et personlig intervju (12.11.04) at nettkommunikasjon i SV ikke lenger var sidestilt med papirkommunikasjonen. Den var blitt hovedregelen for intern kommunikasjon 
i partiet. Men SV nedla også mye arbeid i å bruke nettet til ekstern kommunikasjon. Sammenliknet med andre norske partier har SV gått lengst i å argumentere for en nedbygging av skillet mellom medlemmer og ikke-medlemmer (Heidar og Saglie, 2002:65). Ikke minst var bloggen et konkret eksempel på det. $^{7}$

SVs nettsatsing må ses i sammenheng med den politiske situasjonen partiet sto oppe i sommeren og høsten 2004. Partiet pustet Arbeiderpartiet i nakken, med opp mot 20 prosents oppslutning. Ledere og medlemmer så for første gang en reell mulighet til å inngå i en samarbeidsregjering med Arbeiderpartiet og evt. Senterpartiet. Ifølge Halvorsen var lanseringen av bok og hjemmeside starten på en politisk visjon, en rød-grønn flertallsregjering. Dette visjonære målet skulle ledsages av udogmatiske valg av virkemidler. Bloggen ble introdusert med partileder Kristin Halvorsen som krumtapp. Bloggen var særlig inspirert av den amerikanske presidentvalgkampen i 2004, som førte blogging ut av mørket og inn i den store medieverden. Alle de fremste presidentkandidatene hadde egen blogg. Også europeiske politikere hadde begynt å blogge. Den første britiske politiker begynte å blogge i 2003.

Halvorsens bok- og hjemmesidelansering må videre ses i lys av den generelle åpenhet som i lengre tid hadde preget SVs offensiv for å nå velgerne. I boka presenterte Halvorsen ti regler for statsrådvett. Første regel var: «Vær så åpen og tilgjengelig som overhodet mulig» (Halvorsen, 2004:70). Og SV har utmerket seg i forhold til de fleste andre norske partier når det gjelder åpenhet om egne strategier, i alle fall så lenge de satt i opposisjon. Dette kom frem da vi i 2004/05 intervjuet norske partier om bruk av IKT i partiarbeid og politisk kommunikasjon. Av SV fikk vi tildelt en rekke interne strateginotater. SV var også det eneste norske partiet som lot forskere følge interne møter og diskusjoner over lengre tid. I tillegg til beretningene om partiets strategier frem mot stortingsvalget 2005, var partiets representanter åpne om partiets medieovervåkingssystem og om styrte lekkasjer til mediene. Videre erkjente partiets representanter at de hadde lært mye av mediestrateger i andre land: De fortalte om pressesekretærer som ble sendt på kommunikasjonskurs i Washington og om et lærerikt Oslo-besøk av Joe Trippi, valgkampleder for USAs tidligere presidentkandidat Howard Dean. ${ }^{8}$ Trippi var den som i 2004 initierte «den store amerikanske konversasjonen" rundt Deans valgkamp, en konversasjon basert på en rekke online-virkemidler, alt fra weblogger til chat boards og e-postlister.

Nettet ble i SV fremholdt som en krumtapp i partiets strategiske tenkning rundt åpenhet og debatt. Daværende partisekretær, Bård Vegard Solhjell, hevdet for eksempel: 
Vi har mange unge velgere og sympatisører. Skal vi kommunisere med dem, må vi være i forkant også med virkemidlene, med teknologien. Vi har nok en partikultur som skiller seg fra de gamle partiene. Ønsker man debatt $i$ dag, er internett det beste og mest effektive medium» (Dagbladet, 11.10.2004).

Halvorsen så nettet som en plattform for nye deltakelsesformer og inkluderende fellesskap. I boka nedfelte hun dette i sin tredje statsrådsregel, som var spesifikt rettet mot nettkommunikasjon:

Gjør det enkelt for velgerne å påvirke og si ifra. Sørg for å ha enkle nettsider der velgerne kan få informasjon, få vite hva du har på hjertet og si ifra hva de mener. Sett av tid til å lese folks meninger og svare på spørsmål på disse nettsidene (Halvorsen, 2004:70).

Sammenliknet med alle de andre partiene vi intervjuet, var SV det partiet som virket mest opptatt av å få folk til å bruke nettet aktivt, nesten uansett hva som måtte komme av innspill. "Nettet er en informasjonskanal, og der har vi kommet langt ... men vi ønsker nå mer å bruke det til å knytte sosiale bånd», hevdet Nørbech. En kommunikasjonsweb snarere enn en administrativ brukertjeneste var målet:

Vi vil gi folk eierskap til prosjektet. Vi har lxrt at vi kan slippe kontrollen, fä til eierskap for folk som ønsker å vare med. Vi kan ikke forandre verden for dem. Vi må gjøre det sammen. Vi må inkludere folk. Vi har kommet langt når det gjelder å få ut informasjon på ulike måter. Det neste er å få opp deltakelsen, at folk involverer seg og knytter sosiale bånd. Vi prøver altså å få det til å bli en mer toveisgreie. Målet er at folk skal skrive inn ting, sende en e-post, helst få bygd opp communities, egne nettsamfunn, rundt temaer der folk har sin egen blogg og andre ting som er bra. Alt dette, som tidligere ville krevd et stort apparat, er det nå mulig å få til relativt enkelt. (Intervju med Nørbech, 12.11.04.)

Nettets enkle - og billige - muligheter med hensyn til inklusjon og fellesskapsdannelse skulle dermed bidra til å profilere SV som et «ungt, åpent og moderne parti» (jf. Nørbechs Prosjektplan SVisj-vev, 2002). Vektleggingen av inklusjon, deltakelse og tilgjengelighet kan selvsagt ha vært en midtscenestrategi - også i forhold til forskningen, som her ble invitert inn. La meg også minne om kildens posisjon. Hovedinformanten i SV, Nørbech, var en av partiets store teknooptimister, og dette kan ha farget informasjonen som ble gitt.

La meg nå drøfte Halvorsens trippelutspill, først den noe spesielle boka, deretter bloggen og nettmøtene. Hva var det erklærte prosjektet, målet for kom- 
munikasjonen? Hvordan posisjonerte Halvorsen seg i de ulike mediene med hensyn til et folkelig og personlig lederskap? Hvilken stil og virkemidler inngikk i kommunikasjonen?

\section{Halvorsens folkelige karisma i bok, blogg og nettmøter}

\section{Boka: Et bredt personlig-politisk fremstøt}

I boka Rett fra hjertet viser Halvorsen en usedvanlig sterk formidlingsvilje. Denne er ikke ny. Den kom for eksempel til syne da hun, i likhet med enkelte andre partiledere, ble fast spaltist i Se og Hør høsten 2003. Gjennom å takke ja til å skrive for Se og Hørs 1,6 millioner lesere, uttrykte hun en antielitistisk holdning til formidling. Også boka Rett fra hjertet, som ble skrevet i samarbeid med journalisten Ingolf Håkon Teigene, var rettet mot de brede lag av befolkningen. Men den var ikke ment å være en rent politisk debattbok. Den var heller ikke en vanlig biografi, men skulle derimot - ifølge Halvorsen selv - betraktes som «en personlig politisk bok» (Halvorsens blogg, 28.10.04).

Rett fra hjertet er en enkel bok. Halvorsen har selv sagt at det vil ta rundt to timer å lese de 227 sidene. Det kan nok stemme. Det politiske prosjektet fremkommer gjennom en grei, ikke-kronologisk beretning bestående av gode hovedsetninger - og gode hensikter. Enkelheten blir antakelig enda tydeligere fordi boka ikke rommer fotnoter og referanser. Som nevnt ble de lagt til hjemmesiden. Der gikk også debattene om boka. Dette var altså ingen vanlig bok, men en to-medial bok basert på en prosessuell tilnærming. Den er et eksempel på at nettet kan utvikle tradisjonelle medier i retning av mer toveiskommunikasjon.

Bokas forsidebilde viser en sortkledd partileder med tittelen Rett fra hjertet skrevet i - ja nettopp - hjertehøyde. Halvorsen fremstår med smilende, uanstrengt autoritet, hun er stram og ungdommelig moderne - det siste bidrar retrostilen på bakgrunnstapetet til. Under lanseringen sa Halvorsen at det fins en SV-er i alle, og at målet hennes var å få leseren til å «gjenkjenne SV-eren i seg selv». Et slikt mål krever sin kvinne. På vaskeseddelen til boka står det følgende:

Hun er brennende engasjert, hun er folkelig og nxr, hun har appell til kvinner og menn langt utover de vanlige politiske skillelinjer. Men hva er drivkraften i Kristin Halvorsens engasjement? Hvor henter hun inspirasjon og påfyll? I denne boka byr SV-lederen på seg selv. Hun deler erfaringer, tanker og folelser med oss, og hun har mye på hjertet: Bli med på noe som er storre enn deg selv, sier hun.

Det er særlig de tre uttrykkene «folkelig og nær», «byr på seg selv» og «bli med» jeg har festet meg ved. Det er her Halvorsens personlig-politiske prosjekt 
ligger. Halvorsens «folkelighetspoeng» er at hun og andre politikere ikke må gjerde seg inne i sin egen verden - politikere må ikke skille seg ut i forhold til andre folk. Hun skriver om hvor viktig det er at stortingspolitikere ikke bevilger seg høyere pensjoner enn andre, at det må være samsvar mellom ordninger som gjelder for «folk flest» og for deres tillitsvalgte. Det er ikke måte på hvor mange ganger uttrykket "folk flest" går igjen i boka. Hun forteller også om hvordan livet som folkevalgt kan bli «nerdete» og "spesialisert»: «Vi kan ende som ikke-betalende medlemmer av den eksklusive organisasjonen 'Norsk Politikk'» (Halvorsen, 2004:66).

Når Halvorsen gjennom sin midtsceneprofilering «byr på seg selv», forteller hun om barndom og oppvekst som Hydro-barn i Porsgrunn, om de første årene på Stortinget, om miniskjørtkorrekser fra Hanna Kvanmo, om egne strategier i tv-debatter, om arbeidsfordeling i hjemmet og om en rekke "hårete mål» som kan utfordre og skape begeistring. Men Halvorsen skriver ikke bare om seg selv. Det personlige knyttes til politiske verdier: Hun skriver om renholdere, verdenssult og klodens ulykkelige. Hun skriver om Norge som freds- og miljønasjon og om målet om å bli "verdens beste land for barn». Og hun skriver om mulighetene for å danne det hun kaller en solidaritetsregjering. Det er her hun trenger å få folk til å «bli med» - på noe større enn dem selv.

Stilen i boka er passelig frisk og freidig. Selvkontrollen er like tydelig som de spontane utfallene og karakteristikkene. Boka er fri for rykter og sladder, til enkelte anmelderes savn. Angrep er det heller ikke mye av. Politiske motstandere i eget og andres parti har altså ingen ting å frykte når Halvorsen forteller fra sine år i politikken. Snarere gjør Halvorsen «romslighet» til ett av sine fremste varemerker.

Den krevende balansegangen mellom fløyene i eget parti er viet en del oppmerksomhet. Blant annet skildrer Halvorsen et SV i konflikt på landsmøtet på Lillehammer våren 1999. Det dreide seg om Kosovo-krisen, om hvorvidt SV skulle støtte NATOs krigføring mot Serbia. «Landsmøtet var dager i helspenn og netter uten søvn. Da det var over, måtte jeg smugles ut bakdøra. Jeg så ut som et takras og mistet hår som etter å ha født» (Halvorsen, 2004:98).

Det var sistnevnte utsagn som fikk meg til å se relevansen av Meyrowitz' bok No Sense of Place (1985). Meyrowitz' «mellomsted» mellom for- og bakscene gjelder riktignok først og fremst fjernsynspresentasjoner, men sier likevel noe om den generelle balansegangen som kreves når man ikke har et veldefinert publikum. Halvorsens bok bekrefter det som flere journalister har hevdet, at hun er en av norsk politikks mestere i å manøvrere mellom det politiske og det personlige. ${ }^{9}$ Det er imidlertid noen grenser for hvor nær man kommer Halvorsen. Formidlingsviljen inkluderer i liten grad mann, barn og hjem. De er bare nevnt i bisetninger. Barna nektes konsekvent å bli avbildet. Og «hjemme-hos»- 
reportasjer har aldri vært hennes stil. Formidlingsviljen inkluderer heller ikke de helt interne forholdene i partiet. Dette er en avgrensning mange norske politikere foretar. Men Halvorsen er altså villig til å kommentere egen kropp. Og hun er villig til å kommentere egne kommunikasjonsstrategier, for eksempel når det gjelder å utmanøvrere trauste mannlige motstandere i sentrale fjernsynsdebatter ved humor eller ved å ta på dem (Halvorsen, 2004:88). I slike selvavsløringer går hun lenger enn de fleste norske politikere, idet elementer fra bakscenen spilles ut helt fremme på scenekanten. Hvorvidt denne midtsceneprofileringen oppfattes som legitim og sjarmerende eller ikke, kommer jeg tilbake til under behandlingen av responsen på boka.

Gripsrud forteller om hvordan politikere gjennom det han kaller midtsceneatferd balanserer mellom det å "gi av seg selv», for å vise personlig sjenerøsitet, samtidig som de også forsøker å beholde et minimum av verdighet, og også en viss enigma, som kan gi dem den autoritet de vil trenge når det virkelig røyner på (Gripsrud, 2002; Dagens Næringsliv, 20./21.11.04). Som Meyrowitz plasserer han disse balanseøvelsene mellom for- og bakscenen. Det vil si øvelser som er akkurat passe private og personlige til å være på høyde med medienes grunnleggende estetiske form på den ene siden, og med journalistikkens intimitetstyranniske krav om å være nære og varme på den andre. Nå kan man innvende at i Halvorsens kombinerte bok/hjemmeside er det ingen journalister. Det medierende leddet er tatt vekk. Jeg vil likevel påstå at midtsceneprofileringen dominerer. Det virker som om Halvorsen selv står inne for kravet om nærhet i boka si, også uten et direkte journalistisk trykk. Jeg mener videre at det er mulig å spore en noe ulik midtsceneprofilering i de ulike mediene Halvorsen benytter. Denne ulikheten i profileringen kan blant annet knyttes til graden av inntrykksstyring med hva som slippes ut av informasjon. Bok og hjemmeside gir en stor grad av kontroll over iscenesettelsen. Hva så med blogg og nettmøter?

\section{Bloggen og nettmøtene: hyppig, kort og personlig kommunikasjon}

Selv om både blogg og nettmøter begge ble plassert på Halvorsens hjemmeside, var det forskjell på de to førstnevnte kommunikasjonsformene og hjemmesiden. Riktignok var de alle under stadig omarbeiding, ikke minst bloggen, men de hadde ulike mål og funksjoner. Hjemmesiden var formell og representativ, en "stylet» virtuell ambassadør eller front som hovedsakelig ble brukt til enveisinformasjon ovenfra og ned, uten forstyrrende mellomledd. Deler av SVs partikontor var her flyttet på nett, og hjemmesiden minnet slik sett om den gamle kontrollerte partipressen, selv om den, symptomatisk nok kalt «Kristins side», var personifisert og modernisert i formen.

I bloggen og nettmøtene var hensikten en annen: å etablere kontakt med andre. Men denne kommunikasjonen rommet ulik grad av inntrykksstyring. I 
bloggen kunne Halvorsen kontrollere mye av debattopplegget selv, legge premissene for hva som skulle diskuteres. Denne kontrollen ga hun slipp på i nettmøtene. Her var det velgerne som bygde dagsorden. De kom med spørsmål og kommentarer om ting de var opptatt av, og Halvorsen svarte som best hun kunne.

Blogging blir best dersom man har et klart mål og fokus med bloggingen, hevdes det i Norskbloggen, en blogg som har påtatt seg å anmelde norske blogger. ${ }^{10}$ La oss derfor se nærmere på Halvorsens mål med bloggen. Under overskriften «Dialogen er i gang - bli med» skrev Halvorsen følgende i sin blogg 29.10.04:

\begin{abstract}
I boka mi reiser jeg store spørsmål som krever svar. Men jeg innrømmer at jeg ikke kan finne alle de gode svara aleine. Jeg må få folk i tale. Det største privilegiet jeg har som politiker er alle menneskene jeg møter. Enkeltmennesker som gjør en forskjell. [...] Jeg vil kommunisere direkte med flere av disse. Hoppe over omveiene/filtrene: Sende på en annen frekvens. Finne en direktekanal til folk, lesere, velgere-engasjerte mennesker med vilje, onske, lyst til å gjøre en forskjell, til å vare større enn seg sjol.
\end{abstract}

Halvorsen ville altså få folk i tale - kommunisere direkte - uten filtre og omveier. Dette er bloggens styrke. I og med at Halvorsen var første norske partileder med egen blogg, bidro denne til noe av den fornyelsen som Weber mente var et viktig trekk ved karisma. Bloggen ga henne anledning til å bygge et personlig politisk lederskap basert på nærhet, folkelighet og tilgjengelighet. SVs omland fikk anledning til å «browse» gjennom hennes personlig-politiske prosjekt i til sammen 40 postinger, ikke medregnet rådgiveren Roger Østlie Sandums fire postinger (sistnevnte steppet inn dersom det «kokte rundt øra på Halvorsen").

Bloggsjangeren har, ifølge Evan Williams, skaperen av det anerkjente bloggverktøyet "Blogger», tre hovedtrekk: Den er hyppig, kort og personlig (Mortensen og Walker, 2002). Halvorsens blogging var hyppig, i alle fall i første fase. Fra oppstart 26. oktober 2004 og frem til nyttår, en drøy tomåneders periode, omfattet bloggen totalt 33 postinger. Det ble i gjennomsnitt en posting annen hver dag, med noe mer aktivitet i ukedagene enn i helgene. I perioden fra nyttår og frem til juni foregikk det et taktskifte. Da ble det postet bare 11 ganger - i gjennomsnitt to ganger i måneden - men med stadig dalende aktivitet.

Som sjangerdefinisjonen tilsier var Halvorsens bloggpostinger relativt korte. Lengden varierte riktignok noe, fra fire til 44 linjer. Gjennomsnittslengden var på 17 linjer, 192 ord. Halvorsens nettmøtesvar var noe kortere. De varierte fra én til 53 linjer med et gjennomsnitt på 11 linjer, 125 ord. 
Hva så med det personlige ved bloggen? Her var oppfatningen i partiet at det var viktig å fremstå som en "genuin» blogger. To eksempler ble gjerne trukket frem. Det ene var Labour-politikeren Tom Watson. Han ble av mange regnet som den beste bloggeren i Storbritannia, noe som angivelig hadde omgjort mannen fra backbencher til frontbencher. Et mindre heldig eksempel som ble nevnt, var den tidligere danske statsministeren Poul Nyrup Rasmussens blogg. Mens førstnevnte angivelig fremsto med et genuint ønske om å blogge, skal Nyrup Rasmussen ha startet bloggingen fordi medierådgivere fortalte ham at dette var in. Her kan Goffmans begrep om rolleinnlevelse gi mening. Begrepet sier noe om hvordan man kan gå helt opp i rollen sin, tro på den. Kynikeren derimot, som Goffman også beskriver, er en som skaper distanse til sin egen rolle, en som ikke tror på sine egne handlinger (Goffman, 1992:25).

Det fantes sterke meninger i SV om hva som var god og dårlig blogging, ikke minst om hva som var dårlig. Og blogging kan raskt bli en klisjéfylt øvelse. Men blogging kan også gjøre politikere mer «levende» ved å gi dem et mer direkte og avslappet språk, et språk som åpner for debatt. Webredaktør Nørbech understreket at SV med www.svkristin.no, og ikke minst gjennom bloggen, hadde tatt «et langt steg nærmere velgerne». ${ }^{11}$ Både han og Halvorsen bekreftet videre at SV gjennom hjemmesiden åpnet for mer personfokusering i politikken.

Ifølge Voxpolitics, en blogg om politisk blogging i Storbritannia, ${ }^{12}$ virker blogging best når politikeren, på en ærlig og åpen måte, gir av seg selv. Men man må heller ikke overdrive. Narsissisme og selvrettferdighet faller gjerne dårlig ut. Hver politiker må finne sin egen stemme, hevdes det: Til mer naturlig, til bedre er det. Derfor kan man vanskelig overlate bloggingen til andre. Videre hevder Voxpolitics at blogging på sitt beste kan bidra til å lufte meninger og spørsmål åpent og lyttende. Dette er potensielt interessant. Selv har jeg tilbrakt mangfoldige timer med å analysere politiske fjernsynsdebatter og har sett hvor lett politikerbudskapene går på autopilot, blir rutiniserte og kjedelige. Velgerne går lei. Og politikerne hevder å bli lei av seg selv (Krogstad 1999, 2004b). Jeg har også sett hvor ugreit det er for politikere å ta inn over seg andres synspunkter. Det er da heller ikke meningen med de fleste politiske debatter. Det er forhåndsbestemte oppfatninger man skal fremme. Dette kan altså være annerledes i bloggdiskusjonene.

Hva forteller Halvorsen om i bloggen, og på hvilken måte? I tillegg til store politiske saker, ikke minst saker i nyhetsbildet, kunne postingene omtale planlagte besøk, konferanser, demonstrasjoner, hårfrisyrer, legge- og våknetider og daglige møteplaner - alt i et kvikt, direkte og muntlig språk. Halvorsens nettkommunikasjon kan sies å ha ligget et sted mellom chat, e-post, dagbok og politisk kommentarvirksomhet. Sammenliknet med synkron og stedsbundet ansikt-til-ansikt-kommunikasjon, var dialogen i bloggen diakron og ikke-loka- 
lisert. Bloggen ga Halvorsen mulighet til å tenke seg om, den ga tid til baksceneforberedelser (Rasmussen, 2003b). Nettmøtene derimot, var mer synkrone enn bloggingen i den forstand at nettmøtene i hovedsak var lagt til bestemte tidspunkter. Halvorsen kunne altså ikke vente med å svare til hun var parat til det. Dette, pluss det faktum at hun ikke kunne bestemme tema for diskusjonen, ga mindre inntrykkskontroll.

Halvorsens skrivestil virket relativt spontan og personlig. Noen bloggpostinger var klassisk dagbokstoff, som da hun den 30. oktober 2004 skrev: «I dag har jeg en sløve-dag hjemme i Oslo med en bunke aviser.» Dagen etter, som var en søndag, skrev hun følgende:

\begin{abstract}
En sløvedag til med bøker og aviser. (Leste ferdig Anne B. Ragdes bok; Berlinerpoplene. Anbefales!) Skal innom Nei til EUs kvinnekonferanse i ettermiddag - det er snart 10 år siden folkeavstemningen om norsk EU-medlemskap. Jeg har skrevet noe om dette i boka og om hvorfor jeg mener det er viktig at SV gjør klart at i en eventuell ny folkeavstemming om me... Les mer
\end{abstract}

Som leseren vil skjønne, måtte man trykke på «Les mer» for å få med seg resten av bloggen. Og dette var faktisk et selvstendig poeng. Man skulle etter noen få sekunders lesning klikke seg videre. Dette ville gi inntrykk av interaktivitet, av at noe var i ferd med å skje, hevdet partiets webredaktør.

Selv om Halvorsen styrte bloggen, åpnet hun også for råd og innspill. Eksempelvis ba hun den 23. februar 2005 om innspill til diskusjonen om hvorvidt abortgrensen skulle utvides fra 12 til 16 uker. Til dette fikk hun 50 innspill (ironisk nok overveiende fra menn, noe webredaktøren registrerte og underveis ba kommentatorene gjøre noe med). Poenget med rådslagningen var at Halvorsen gjennom bloggen skulle kunne fange opp meninger «der ute». Dette med å fange opp meninger var enda viktigere i nettmøtene. Her var poenget å «lytte» vel så mye som å «snakke».

Enkelte av Halvorsens postinger kunne virke uinspirerte. Men stort sett var hun formidlingssterk, klar, til tider diplomatisk, til tider kontant uenig, ganske morsom og varm. Først og fremst skåret Halvorsen på sin direkte stil og muntlighet. Hun kunne legge det saklige og tørre politikerspråket til side. Et eksempel er "massevis av positive tanker" som hun sendte til en som hevdet å være deprimert. Etter å ha fått kjeft av en nettmøtekommentator for bare å svare på hva hun selv gadd, kalte hun ham «surpomp!» etterfulgt av utsagnet «Jeg jobber som hakka møkk for å svare alle!». Hun lovet en av leserne å «klaske til mot Hagen", hun skrev at i valgkamp "er det kjøttvekta som teller» og at Bush hadde "herpa økonomien, økt arbeidsledigheten og med løgn og manipulering ført USA til krig mot Irak». Sterke saker fra en som senere skulle bli Norges 
finansminister. Hun nevnte et 20 år gammelt tv-klipp fra en debatt hun hadde deltatt i: «Da var jeg ung og uskyldig - nå har jeg blitt et gammelt råskinn i forhold». Og hun vurderte «å juge på seg noe pikant», muligens noen "saftige sexhistorier" i et bilag til boka for å vinne kampen om medieoppmerksomheten. Og, som vanlig, oppdaget hun at "sex selger». Sistnevnte utspill ble plukket opp av papirpressen.

Det var ikke bare budskapene i Halvorsens nettkommunikasjon som var interessante, men også de tegnene som, i Goffmans forstand, ble avgitt mellom linjene (Rasmussen, 2003b). Mens man i ansikt-til-ansikt-kommunikasjon kan tolke både verbale og ikke-verbale trekk (blikk, smil, nikk etc.), gir nettkommunikasjon færre muligheter. Halvorsens ordvalg, språk og stil på nett bidro likevel til både å gi og å avgi inntrykk - av engasjement, innlevelse, irritasjon eller frustrasjon.

Om Halvorsens blogging også kan beskrives som sjarmerende, var det antakelig fordi den ga inntrykk av å komme «rett fra levra», nærmest spontant og ufrivillig. Og i nettmøtene posisjonerte hun seg slik at nettspørsmålene tilsynelatende gikk "rett i øret». Men hvor «bredt» var bredbåndet mellom Halvorsens hjerne, tastatur og postinger? Var denne kommunikasjonen egentlig så spontan og direkte? Her ville antakelig Goffman bedt oss om å ta en liten tenkepause. Til tross for det umiddelbare og uformelle tilsnittet ved nettkommunikasjonen, kunne ikke Halvorsen tillate seg å glemme at den faktisk var både offentlig og formell. I motsetning til mange av nettkommentatorene kunne ikke Halvorsen opptre anonymt i blogg og nettmøter. Hennes online-personlighet ga begrensede muligheter for spontanitet og eksperimentering. Midtsceneprofileringen på nett lå nær opp til forscenen, selv om elementer fra bakscenen ble porsjonert ut. Hver posting ble lagret i et arkiv som alle hadde tilgang til. Som formell representant for et parti kunne ikke Halvorsen slenge ut ugjennomtenkte ytringer. Hun var ikke en hvilken som helst aktør. En partileder og rikskjendis vil hele tiden betraktes. Hver uttalelse kan potensielt havne som frontsak i andre, mer etablerte medier. "Rett fra levra»-kommunikasjon, inkludert det Goffman betegner som de mer rå og upolerte sidene ved bakscenen, ville være en umulighet.

Likevel - uttrykk forankres gjerne i myter om at de er ukalkulerte, spontane og ufrivillige, hevder Goffman (1963:14). Han er samtidig rask til å tilføye at de også - i noen tilfeller - faktisk er det. Goffman tar altså ingen ting for gitt. Dikotomien «frivillig-ufrivillig» er en av de minst uskyldige i vår bransje, påstår han (Goffman, 1963:14). Posisjoneringene og virkemidlene i Halvorsens «umiddelbare» midtsceneprofilering på nett var på forhånd gjennomgått og anbefalt av partistrateger. Her ble det angitt en hovedretning for den strategiske nettkommunikasjonen når det gjaldt modighet, klare meldinger, tøffe krav, forståelig 
språk samt visjoner, en retning Halvorsen fulgte. Om slik strategisk profilering kan virke «kynisk» og villedende, vil Goffman igjen ile til med å fortelle oss at kynikeren ikke nødvendigvis villeder sitt publikum av egen interesse: den kan vel så godt være ment å bidra til publikums, eller samfunnets, eget beste (Goffman, 1963:29). Ifølge Anders Horn (Ny Tid, 01.11.04) forsøkte Halvorsen å overbevise velgerne om at "alle tjener på mindre forskjeller og mer fellesskap».

Selv om politisk kommunikasjon først og fremst dreier seg om planmessig, strategisk kommunikasjon, er Goffmans bidrag at han fremmer flere mulige lesninger av samme fenomen. Om det enkelte uttrykk som gis og avgis er bevisst/intendert eller ikke, vil alltid være grunnleggende vanskelig å avgjøre, til og med for den som selv kommuniserer. Det som i utgangspunkt kan ha vært en "tom» symbolsk atferd, en ren gimmick, kan gjennom bruk skape mening, bli noe man tror på. Om det var dette som skjedde med Halvorsens blogging, er tvilsomt. Man kan snarere tenke seg en omvendt prosess: Det som man i utgangspunktet hadde trodd sterkt på, blogging og nettmøtekommunikasjon, ble - etter hvert - tømt for betydning i forhold til annen, mer etablert kommunikasjon etter hvert som man nærmet seg valgdagen.

\section{Responsen på bok, blogg og nettmøter}

\section{Responsen på boka}

Som tidligere nevnt, kalte Halvorsen boka Rett fra hjertet en personlig politisk bok. "Hva er nå det?» kan man spørre. På dette punktet fikk Halvorsen en rekke tilbakemeldinger. Jeg vil trekke frem 21 avisanmeldelser de første to månedene etter utgivelsen samt 23 debattinnlegg om boka på Halvorsens hjemmeside. Poenget med å trekke frem disse reaksjonene er at et personlig politisk lederskap hovedsakelig ligger i øynene som ser, i selve mottakelsen. Tilsvarende hevder Weber at karismatisk lederskap først og fremst ligger i folks anerkjennelse av dette, ikke i lederens eventuelle egenskaper.

Avisanmelderne var først og fremst journalister, men også politikere og fagpersoner (filosofer, idéhistorikere) anmeldte boka. Ut over to usignerte kommentarartikler besto anmelderkorpset i avisene av 14 menn og fem kvinner. I nettdebatten deltok 20 menn, én kvinne og to anonyme kommentatorer. Flere sider ved boka ble tatt opp i avisanmeldelser og nettdiskusjoner. I denne gjennomgangen vil jeg se på vurderingene av virkemidlene - nærmere bestemt reaksjonene på bokas sjanger/form - samt vurderingene av det personlig-politiske ved boka.

Sjefredaktør Tom Hetland i Stavanger Aftenblad (11.11.04) kalte boka en blanding av biografi og politisk programskrift, ispedd noen anekdoter fra det politiske livet. Dels memoarbok, dels politisk sjølmelding var også et uttrykk 
som ble brukt. Sjangermessig, hevdet en anmelder, kunne boka vært «referatet fra en samtale i sene nattetimer rundt kjøkkenbordet eller et cafébord over noen flasker vin». Få av anmelderne så ut til å få med seg det prosessuelle, det bevisst uferdige ved boka. Den ble i hovedsak vurdert som en tradisjonell bok. Og her mente de fleste at den i sin enkelhet kom til kort. Av de mest negative uttrykkene som ble nevnt var «tabloid og grunn». Det ble hevdet at Halvorsen «jabber seg gjennom likt og ulikt» og at boka virket «uferdig». Hun ble oppfordret til å komme tilbake når tankene var «mer ferdig fordøyet». "Boka analyserer og forklarer, uten å problematisere», ble det også hevdet.

Halvorsen fikk her heftigere kritikk enn den "kosekritikken" hun til da hadde pleid å få i mediesammenheng. Noen anmeldere lot seg likevel, nesten litt motvillig, bevege et stykke og mente Halvorsen hadde et realt prosjekt. Noen så også et mer langsiktig valgkampperspektiv i "Kristins l. bok», en oppfordring til velgerne om «en verdimobilisering i norsk politikk». Det ble rost selv om noen mente at den rød-grønne fremtidsvisjonen virket noe pompøs. Også kombinasjonen bok/hjemmeside ble berømmet som en «ny gimmick» (i positiv forstand) og en oppmuntring til fortsatt debatt om temaene i boka. I og med at Halvorsen etter hvert fikk mange omtaler, ikke minst i tabloidavisene (samt en rekke kommentarer på hjemmesiden), mente mange anmeldere at hun hadde lykkes.

Når det gjelder vurderingene av Halvorsens personlige gjennombruddskraft i boka, var det stor uenighet i anmelderkorpset. Antakelig var Jørgen Haavardsholm (Sakprosa, 28.09.04) den mest negative. I artikkelen «En partileders betroelser» kritiserte han Halvorsens blanding av politikk og privatsfære:

Hennes åpenhjertighet $i$ boka beveger seg fra det personlige, allmennmenneskelige og over i privatsfxren. Teksten skjemmes av et intimspråk og en rekke private opplysninger om Kristin Halvorsen selv og hennes familie, som ikke har relevans for andre enn en svart liten krets. Jeg ser ikke bort fra at kvinner likevel vil kunne lese hennes betroelser med et noe annet blikk. Teksten henvender seg nemlig forst og fremst til de unge, dynamiske, fremadstormende kvinnene, pluss/minus 30 år, som forsøker a kombinere et rikt privatliv med en meningsfull karriere.

Haavardsholm konkluderte med at det litterære grepet ble "hakket for privat». Han hevdet selv å bli «mer overbevist av godt formulerte argumenter.»

Én av anmelderne, Trond Berg Eriksen, snudde imidlertid fra å være negativ til å bli positiv. I sin anmeldelse i Morgenbladet 26.11.04, fortalte han at han aldri hadde likt dem som brukte ærlighet som egenreklame, og at han oppfattet det som «temmelig grisete å blande hverdagsrapporter fra familielivet med politiske salgsfremstøt». Etter å ha lest boka, lurte han imidlertid på hvorfor Halvorsen 
"glimtvis likevel greier det umulige». Han satt igjen med en følelse av å ha blitt «klokere og sjarmert» uten å føle seg narret. Særlig likte han bokas bilde av blondiner mot EU, der Halvorsen var æresblondine. Samtidig la han tørt til at bildet av blondinene antakelig var det eneste gode argumentet mot EU-medlemskap som hadde krysset hans vei. Berg Eriksen var også positiv til Halvorsens mediekapittel idet han hevdet at «kravet om alltid å væere på høyden, overbelyst og på offensiven - også når man har fett hår og skulle ha lagt seg for tre timer siden - er rent oppbyggelige påminnelser for oss som står uten politiske verv».

Mest ros fikk Halvorsen for den helt elementære omsorgen og omtanken for de svakeste i samfunnet. «Dessuten», la Berg Eriksen til, snakket Halvorsen «som mor med kunnskap og engasjement om barnehager og oppvekstvilkår». For ham var altså det personlige moderskapet med på å gi legitimitet og troverdighet til det politiske engasjementet. Her ble Halvorsen trodd.

Om det finnes et minste felles multiplum i anmelderreaksjonene, må det være at Halvorsens bok kan kalles et personlig-politisk fremstøt. Men det har hun selv sagt. La meg derfor oppsummere avisanmeldernes respons ved å vise bredden i reaksjonene. Anmelderne mener at:

1 Halvorsen er for privat (Jørgen Haavardsholm, Sakprosa, 28.09.04)

2 en behagelig ærlighet kommer til syne, men uten å ha noen funksjon (Hanne Andrea Kraugerud, Morgenbladet, 29.11.04)

3 hennes selvbiografiske skildringer er for lite systematiske og uttømmende (Anders Horn, Ny Tid, 30.10.04)

4 hun kunne gitt mer av seg selv (Arve Øverbø, $V G, 08.12 .04$ )

5 hun er personlig, men ikke privat (kommentar, Dagsavisen, 29.10.04)

6 de selvbiografiske skildringene gir legitimitet og troverdighet, og har dermed en funksjon (Trond Berg Eriksen, Morgenbladet, 26.1 1.04)

7 hun er ekte og naturlig (Ole Kr. Mortensen, Magasinet Aktuell, 15.11.04)

Som vi ser er det et stort sprik i tilbakemeldingene når det gjelder Halvorsens angivelige pendling mellom det personlige og det private, det ekte og det uekte (en «behagelig» ærlighet) og det kulturelt sett legitime og det illegitime ( «for privat»). Dette i seg selv tyder på at man her har støtt på en ustabil mellomkategori, en midtscene, der det er noe uklare oppfatninger om hvor grensen mellom scene og bakscene skal gå. De førstnevnte anmelderne bifaller ikke at elementer fra det de regner som bakscene spilles ut på hovedscenen. Bare de sistnevnte anmelderne ser ut til å la seg overbevise av Halvorsens prosjekt slik det fremstilles i boka, og det fordi de mener å se konsistens i opptredenen på og av scenen. Til tross for spriket i tilbakemeldingene sier de mange avisanmeldel- 
sene og nettdiskusjonene noe om interessen for Halvorsens personlig-politiske prosjekt i forhold til et sentralt posisjonert, innflytelsesrikt og mannlig dominert anmelderkorps.

\title{
Responsen på blogg og nettmøter
}

Hva slags respons fikk Halvorsen på blogg og nettmøter? Her er de første begeistrede tilbakemeldingene, meldinger som først og fremst berømmet henne for fornyelsen av den politiske kommunikasjonen: «Flott tiltak! Håper flere politikere vil begynne å kommunisere direkte med velgerne». "Flott med Blogg Kristin Halvorsen! Stå på! Deg i sjefs-stolen hadde vært tingen!!». "Godt å oppleve at i hvert fall én politiker henger med i den nye tid - den digitale, og vil ha dialog! Gratulerer Kristin!». Her er et regelrett fan-innlegg fra første nettmøte:

\begin{abstract}
Kjxre nabo og favorittpolitiker, jeg er en av dine mange fans og da jeg støtte på deg $p a ̊$ vår felles Rimi-butikk tidligere $i$ år skvatt det ut av meg "Jeg elsker deg, jeg digger deg!» og du holdt på å le deg ihjel. Ser du på folk som undertegnede som sproyte pine gal eller tar du til deg selv disse gale uttrykk for beundring? Gleder meg allerede til a gi deg blomster på Slottsplassen neste år. Stå på videre! Av: Geir, 29 Oktober 2004 09:34
\end{abstract}

Svar:

Sånne naboer skulle flere hatt! Hva er vel bedre enn begeistrede tilrop i køen til kassa på Rimi en gusten oktoberdag! Håper flere kan oppleve sånt! Andreas Hompland $i$ Dagbladet for eksempel :-) kristin

I motsetning til mange andre medier, gir blogg og nettmøter folk mulighet til å kommentere, stille spørsmål, komme med meninger, til og med «drittpreik». Når det gjelder siste punkt, var mange av de tidligste kommentarene skrevet av høyreorienterte kverulanter. Men disse hang ikke med lenge. Tonen ble etter kort tid overveiende saklig og god, for så igjen å bli småhissig på grunn av Halvorsens stadig sjeldnere postinger. Bare én gang så jeg SVs nettredaktør korrigere bloggdebattantene, men da i form av en oppfordring til jenter/damer om å melde seg på abortdebatten. Nettredaktørens prinsipielle oppfatning var å la det meste kunne stå på trykk, både det positive og det negative: «Det vil ikke komme på avveie. Dette er noe man bare må tørre.» ${ }^{13}$

Hvem var det så som oppsøkte og kommenterte SVs nettsider? Ut over kjønn er det vanskelig å si noe autoritativt om det. Generelt kan det hevdes at den typiske SV-velger er en ung, velutdannet kvinne ansatt i offentlig sektor. Ved valget i 2001 utgjorde kvinnene 60 prosent av SVs velgere (data fra 2005 er ennå ikke tilgjengelige). Av de under 30 år var to tredeler kvinner. Bildet foran- 
drer seg imidlertid med alder. Av SVs velgere over 50 år er det flest menn. Jeg har en mistanke om at en del av disse er aktive bloggere med uhyre god tid.

Surveydata fra Velgerundersøkelsen i 2001 viser at besøk på partienes nettsider i valgkampsammenheng domineres av unge og unge voksne. Det er liten variasjon i utdanningsnivået til de besøkende. Det er også liten forskjell mellom kvinner og menn, men kjønnsforskjellen øker med økt alder. Ti prosent av dem som stemte SV ved dette valget, hentet også informasjon fra partiets hjemmeside. Surveyundersøkelsen gjelder imidlertid besøk i en aktiv valgkampperiode og er ikke nødvendigvis representativ når det gjelder kommentarvirksomhet utenom aktiv valgkamp, som i Halvorsens første periode med nettkommunikasjon.

I tabell 1 gis en oversikt over responsen, dvs. omfanget av bloggkommentarer og nettmøtespørsmål, samt kjønnsfordeling. Første bloggperiode dekker perioden fra oppstarten 26. oktober frem til nyttår. Andre periode, som har betydelig færre postinger fra Halvorsens side, dekker perioden fra 1. januar og frem til juni måned 2005, da Halvorsen la ned bloggen.

Tabell I. Respons på blogg og nettmøter, med kjønnsfordeling. Prosent i parentes

\begin{tabular}{lcrrrr}
\hline & Blogg & \multicolumn{1}{c}{ Blogg } & 1. nettmøte & 2. nettmøte & \multicolumn{1}{c}{ Totalt } \\
\hline Alle innlegg & $208(100)$ & $341(100)$ & $46(100)$ & $53(100)$ & $648(100)$ \\
Menn & $158(76)$ & $238(70)$ & $24(52)$ & $38(72)$ & $458(71)$ \\
Kvinner & $22(11)$ & $41(12)$ & $19(41)$ & $11(21)$ & $93(14)$ \\
Ikke oppgitt kjønn & $28(13)$ & $62(18)$ & $3(7)$ & $4(7)$ & $97(15)$ \\
\hline
\end{tabular}

Hvor stor respons mottok Halvorsen på bloggingen? I første periode fikk hun 208 bloggkommentarer, i gjennomsnitt syv per posting. I andre periode, da Halvorsens postinger dabbet av, fikk hun totalt 341 kommentarer, i gjennomsnitt 34 kommentarer per posting. Dette er en relativt beskjeden respons på en partileders blogg. Men forskning i Norge viser så langt at politisk deltakelse på nett er begrenset (Saglie og Vabo, 2005; Saglie, 2007). Til sammenlikning fikk heller ikke partilederen i det danske Sosialistisk Folkeparti, Holger K. Nielsen, mye respons på sin blogg - bare noe i overkant av én kommentar til hver av sine bloggpostinger (Holger K's blog). Den svenske politikeren Carl Bildt fikk i underkant av fire kommentarer til hver posting de fire første månedene han blogget i 2005 (carlbildt.wordpress.com), selv om hans blogg nå har tatt av.

Halvorsens to nettmøter fikk henholdsvis 46 og 53 innsendte spørsmål. Hun svarte selv på 22 av de 46 spørsmålene i første nettmøte. Resten av svarene ble overlatt til hennes rådgiver, Mattis Michaelsen. Dette skapte murring blant kommentatorene. I nettmøte nummer to, som også inkluderte tidligere innsendte spørsmål, svarte hun selv på alle spørsmål.

Tabell 1 viser at responsen på Halvorsens blogg og nettmøter kom over- 
veiende fra menn. De sto for 71 prosent av den totale nettresponsen, kvinnene for 14 prosent og de uten oppgitt kjønn for 15 prosent. Den skjeve kjønnsfordelingen samsvarer med resultatene fra internasjonale studier av politiske nettdebatter (se Coleman, 2001). Kjønnsfordelingen er mer ujevn enn det Hestvik (2004) finner i sin studie av online-debatter blant Sps, Vs og SVs velgere i valgkampen høsten 2001 (her var det imidlertid åpne e-postlister som fungerte som debattfora). I Hestviks studie var den totale fordelingen 74 kontra 26 prosent i mennenes favør. Riktignok var den i SV noe jevnere, med henholdsvis 66 kontra 34 prosent. Det betyr at kjønnsforskjellene blant SVs nettkommentatorer var større i 2004/05 enn i 2001.

Om SV gjerne kalles et interesseparti for unge kvinner, er det altså menn som dominerer nettkommunikasjonen i partiet, ikke minst bloggkommentarene. Selv Halvorsens mest populære bloggposting, med den megetsigende tittelen «Hår i politikken ... - jeg rømmer!», fikk 54 kommentarer fra menn, 17 kommentarer fra folk som ikke oppga kjønn - men ingen kommentarer fra kvinner. Også Halvorsens 8. mars-gratulasjon fikk mest respons fra menn. Totalt sett hadde kvinnene ikke bare færre innspill. De hadde også kortere innspill. Av gjengangerne var det flest menn. Og menn inngikk hyppigst i oppfølgingsdebatter med hverandre. Kvinnene var mer aktive i nettmøtene enn i bloggkommentarene. Kanskje var de mer fortrolig med å stille spørsmål, som nettmøtene åpnet opp for, enn å komme med meningsytringer og kritiske kommentarer, som bloggen i større grad inviterte til. Innholdsmessig var kvinnene noe mer erfaringsorientert, mens menn oftere var meningssterke, et funn som også fremkom i Hestviks (2004) studie.

Mottakelsen av den digitale Halvorsen var ikke bare basert på det aktuelle nettmediet, men også basert på det kjennskapet vi allerede hadde til henne fra andre medier. For eksempel hevdet Trond Berg Eriksen i sin omtale av boka at det var «gjenlyden i leserens hode av Halvorsens nasale stemme som tross alt individualiserer teksten" (Morgenbladet, 26.11.2004). Jeg vil for egen del legge til at jeg gjennomgående hørte Halvorsens tjukke «l»-er og a-endelser også i blogg og nettmøter.

Hva så med tonen og virkemidlene i nettkommentarene? Debattantenes kallenavn sa en del: "A.Nonym», "Laban», «brunerune», «ladiesinaction §", «pyttsann», «norvegia», «Someone», «En sur fis til Andre Sæteren», «Livet etter soning v/ Robert og Ole». Kallenavn kunne endres etter som diskusjonene utfoldet seg: "Kokken Pål» kalte seg etter hvert «KokkenpasifistPål». «Sure sokker fra BonBon» ble til «Enda surere sokker fra BonBon» for så, etter nærmest å ha meldt seg ut av debatten, å bli til «Sure sokker gjør comeback». Anonymiteten, som 16 prosent av bloggerne og syv prosent av nettmøtedeltakerne skjulte seg bak, gjorde det sannsynligvis enklere å delta. De digitale fin- 
landshettene gjorde det også lettere å eksperimentere og prøve ut grenser. Når man ikke ser hverandre, som i ansikt-til-ansikt-kommunikasjon, vil man ikke så lett identifisere seg med andre, noe som kan legge til rette for fiendebilder som blir overdrevet i sort/hvitt (Kummervold, 1998:113). Men stort sett ble utskjellinger og saboteringsforsøk ignorert. Og det var flere eksempler på at kommentatorene korrigerte hverandre når ting skled ut. "Sure sokker fra BonBon» fikk følgende korreks fra gjengangeren Per Øhrn:

\footnotetext{
Det er all grunn til å vare skeptisk til mye. Blant annet er jeg skeptisk til folk som ikke våger å hevde sine meninger under fullt navn. Du har for øvrig valgt deg et Pseudonym som kan passe tror jeg. Slikkeriet Sure Sokker inneholder vel ingen naturlige råvarer. Kun syntetiske ...» (14.01.05).
}

Sammenliknet med avisanmelderne, fremhevet blogg- og nettmøtekommentatorene budskapene sine på andre og friskere måter. Store bokstaver ble av og til brukt: "SKREKK OG GRU hvis SV og SP kommer i regjering til høsten». "Nå må du og alle andre rødstrømper FAEN MEG TIL Å SKJERPE DERE!!!». De store bokstavene, ofte kombinert med frodig banning, ga inntrykk av at budskapene nærmest ble ropt ut. Noe av den samme effekten ble oppnådd gjennom løssluppen bruk av utropstegn: «Slike holdninger som du har gjør meg kvalm!!!!!!!!!!». Videre var det en livlig bruk av pausepunktumer og spørsmålstegn: "Så .... hva med å finne fellesnevnere for 'den nye regjeringen'???». Ulike tegn ble til tider blandet: «!?!?». Og man kunne se forlengelse av vokaler «ooops ...», eller onomatopoetiske utrykk som for eksempel «hah», «høh» eller «ko-ko'ene» på Tinget. «Pene» omskrivninger forekom også: «Dra til $\mathrm{h}^{\star * * * * *}$ med sidestillingen deres", hevdet en mannlig kommentator. I tillegg fikk emosjonelle ikoner, som for eksempel smile- og flørtetegn, deltakerne til å virke mer levende og nærværende. Enkelte ganger formidlet smiletegnene godt mente smil: «Ellers så synes jeg du er flink Kristin :)». «Du er ei gromjente ;)». Smiletegnene kunne også ta brodden av krasse eller ironiske uttrykk: «NB! Sidene egner seg veldig bra til kverulering ja - derom ingen tvil :)».

Til sammen bidro disse virkemidlene til et muntlig, uformelt, nesten rått preg. Kanskje kunne de fremstå som litt overflødige samtalekruseduller, som ekstra samtalestæsj. Men de var også noe mer. Ikke bare innholdet, men også formen vil, som Goffman hevder, bidra til å gi og avgi informasjon, skape inntrykk. Det er umulig kun å være saklig (Rheingold, 2000:49-50). I sakligheten er det alltid en tone, en slags musikalitet. Selv tomgangspreik kan bidra til å definere en situasjon - samt fortelle andre hva slags person du er.

Det er noe ironisk at Halvorsen, som i mediesammenkomster med andre politikere gjerne fremstår som den mest folkelige, så ut til å bli noe overkjørt av 
all folkeligheten og selveksponeringen blant nettkommentatorene. En del av debattantenes folkelighet lå et godt stykke unna idealene om saklighetsnormer og deliberativt demokrati. Det kan se ut til at Halvorsen og partiet ikke fullt ut hadde tatt innover seg at nett/blogging ikke er tradisjonell kommunikasjon i ny form, men at selve kommunikasjonen her ble endret. Og den var nok ikke alltid like fristende å delta i. Det er stor forskjell på å snakke til folk, slik Halvorsen gjorde i boka, og å snakke med folk, slik nettet åpnet for. Med Goffman kan man hevde at deltakerne nesten klatret opp på scenekanten. Disse utfordringene ble ikke mindre av at Halvorsen og mange av nettkommentatorene opererte med ulike oppfatninger av hvor langt bakover grensen mellom scene og bakscene skulle trekkes. Potensielt kan dermed midtscenen bli stor. Nettets involverende kommunikasjon kan minne om eksperimentelt teater.

\section{Halvorsens vekst og fall som nettpolitiker}

Siden dette er historien om Halvorsens vekst og fall som bloggende partileder, må man spørre: Hvorfor kollapset bloggen? Sier denne kollapsen noe om internettets begrensninger som ny og sentral politisk arena for moderne politikk? SVs nettstunt utgjør en interessant case fordi man forsøkte å sette ut i livet noen av de visjonene tilhengere av e-demokrati lenge hadde ønsket. Ikke bare SVs e-euforikere, men store deler av den politiske ledelsen hadde sterke motiver for å gjøre dette, en ganske klar ideologi og en god del ressurser. Så langt er Halvorsens nettstunt ett av de mest systematiske og omfattende forsøkene på at internett benyttes til å skape nye og mer direkte politiske deltakelsesformer i Norge. Hvorfor rant det hele ut i sanden?

Antakelig er det lett å undervurdere hvor mye tid nettkommunikasjon tar. Slik kommunikasjon passer heller ikke for hvem som helst. Formen gjør på mange måter politisk appell om til et spørsmål om velgernes direkte tilgang til en politisk personlighet. Halvorsen hadde skapt et forventningspress gjennom å ha startet denne nye kommunikasjonen. Og hun hadde bundet seg til masten ved å nedfelle det hele i en statsrådsregel. Unge Høyres leder, Torbjørn Røe Isaksen, hevdet at løftebruddet ikke lovet godt for en eventuell rød-grønn regjering (Røe Isaksens blogg 22.02.05). ${ }^{14}$ Høyres kampanje- og IT-sjefer kalte SVs nettinitiativ en "typisk gimmick» (her brukt negativt). ${ }^{15}$ Etter hvert fikk Halvorsen massiv kjeft for de stadig større hullene mellom postingene, særlig av gjengangerne på bloggen. Bloggen ble et forum for kritikk snarere enn begeistring. Norskbloggen hevdet at Halvorsens blogg «holdt stø kurs mot den store virtuelle bloggkirkegården». ${ }^{16}$

En grunn til bloggens kollaps var nok at dette var et én-kvinnes show. Forsøket på å gjøre bloggen mer kollektiv gikk ikke for SV. Den var hengslet på 
Halvorsen. Det var rundt henne fellesskapet rundt hjemmeside, blogg og nettmøter ble bygd. Halvorsen fikk heller ikke integrert nettkommunikasjonen godt nok i sitt øvrige politiske liv og program. Dette bekreftes av hennes medarbeidere. Mellom linjene, og på, aner man at det hele blir en ekstra byrde for henne, ikke noe hun gleder seg over å gjøre. ${ }^{17}$ Følgende uttrykk sier noe om Halvorsens tidspress: "Jeg styrter hjem før ...», «jeg rakk ikke å svare på alle ...», «jeg trenger ferie ...». Et par av avskjedshilsenene hennes gjennom de månedene hun blogget, sier sitt: «I full fart fra kristin," eller «God natt!». Som JoFi, en av gjengangerne på Halvorsens blogg hevder, skal man "ha skrivekløe og spesiell interesse for å oppdatere en blogg over tid». Man kan undre seg over om Halvorsen, i tillegg til å være partileder, også skulle få tid til å være en bloggende finansminister (selv om Sveriges utenriksminister Carl Bildt blogger jevnlig). På tidligere spørsmål om hvordan livet ville bli dersom SV faktisk fikk regjeringsmakt, hevdet Halvorsen, litt selvironisk, at «mitt privatliv blir et tapsprosjekt i dette ..." (Kvinner og klar, 19.04.05).

I sin aller siste blogg før sommeren 2005 fortalte Halvorsen at det ganske raskt viste seg at det hadde vært svært krevende å bruke så mye tid på blogg og nettmøter som brukerne forventet. Det å diskutere skikkelig med hver og en "tillater ikke mitt tidsskjema», fortalte hun: Det ville "gått ut over alle dem som henvender seg til meg og oss via andre kanaler». Disse andre kanalene ble vurdert som viktigst da man nærmet seg den intense delen av valgkampen. Dette bekrefter noe samtlige norske partiers nettansvarlige fremholdt i intervjuene: at nettmediene fremdeles regnes som «lillebror» i forhold til etablerte medier.

\section{Rett fra hjertet, rett fra levra, rett i øret}

Teoriene til Weber, Goffman og Meyrowitz kan naturligvis ikke dekke alle sider ved dagens personsentrerte politiske nettkommunikasjon. Men til tross for en viss patina, kan studiene deres gi innspill til forståelsen av hva slags arenaer for personlig-politisk iscenesettelse bok/hjemmeside, blogg og nettmøter utgjør, med ditto profilerte samtaler og dialoger. Karisma, sjarm, inntrykksstyring og mellomsteder utgjør dermed et bakteppe for politikeres offentlige, strategiske midtsceneprofilering i nye medier. Dette blir ikke minst sentralt dersom det forholder seg slik Rasmussen (2003a) antyder, at den personlige websiden kan ses som et bestemt historisk stadium når det gjelder selvpresentasjon. Men om dette stemmer, er det også viktig å nyansere. Tabell 2 sammenstiller hovedelementene ved Halvorsens tre kommunikasjonsformer. Den gir en oversikt over Halvorsens mål, midtsceneprofilering og stil/virkemidler, den løfter frem sentrale trekk ved interaktiviteten, og den viser responsens innhold, omfang og kjønnsfordeling. 
Tabell 2. Kommunikasjon i bok/hjemmeside, blogg og nettmøter

\begin{tabular}{|c|c|c|c|c|c|c|}
\hline & $\begin{array}{l}\text { Halvorsens } \\
\text { mål }\end{array}$ & $\begin{array}{l}\text { Halvorsens } \\
\text { midtscene- } \\
\text { profilering }\end{array}$ & $\begin{array}{l}\text { Halvorsens } \\
\text { stil/virkemid- } \\
\text { ler }\end{array}$ & $\begin{array}{l}\text { Interaktivi- } \\
\text { tet/ kommu- } \\
\text { nikasjons- } \\
\text { retning }\end{array}$ & $\begin{array}{l}\text { Kommenta- } \\
\text { torenes } \\
\text { respons }\end{array}$ & $\begin{array}{l}\text { Responsens } \\
\text { omfang og } \\
\text { kjønnsfor- } \\
\text { deling }\end{array}$ \\
\hline $\begin{array}{l}\text { Bok/ } \\
\text { hjemme- } \\
\text { side }\end{array}$ & $\begin{array}{l}\text { "Få folk til å } \\
\text { gjenkjenne SV- } \\
\text { eren i seg selv" } \\
\text { (identifikasjon) } \\
\text { "Bli med på noe } \\
\text { som er større } \\
\text { enn deg selv" }\end{array}$ & $\begin{array}{l}\begin{array}{l}\text { Rett fra hjertet } \\
\text { (ærlig) }\end{array} \\
\text { Personlig poli- } \\
\text { tisk profilering } \\
\text { med full kon- } \\
\text { troll, er } \\
\text { "folkelig og } \\
\text { nær", "byr på } \\
\text { seg selv" og vil } \\
\text { "ha folk med" }\end{array}$ & $\begin{array}{l}\text { Prosessuell, to- } \\
\text { medial tilnær- } \\
\text { ming: deler av } \\
\text { boka på nett } \\
\text { Mange og lange } \\
\text { resonnementer }\end{array}$ & $\begin{array}{l}\text { Boka: fra Hal- } \\
\text { vorsen til vel- } \\
\text { gerne, ikke } \\
\text { interaktiv. } \\
\text { Hjemmesiden: } \\
\text { interaktiv dis- } \\
\text { kusjonsarena }\end{array}$ & $\begin{array}{l}\text { "Sjangeren } \\
\text { uklar", "boka } \\
\text { for enkel", } \\
\text { "uferdig" } \\
\text { Formell, kritisk, } \\
\text { meningsbasert } \\
\text { H. alt fra "for } \\
\text { privat", via "for } \\
\text { lite personlig" til } \\
\text { "ekte/naturlig" }\end{array}$ & $\begin{array}{l}\mathrm{N}=44 \\
\text { (21 avisanmel- } \\
\text { delser og } 23 \\
\text { nettanmeldel- } \\
\text { ser) } \\
\text { Menn: } 77 \% \\
\text { Kvinner: } 14 \% \\
\text { IOK*: } 9 \%\end{array}$ \\
\hline Blogg & $\begin{array}{l}\text { Informere, uten } \\
\text { redaksjonelle } \\
\text { filtre } \\
\text { Etablere kon- } \\
\text { takt, være til- } \\
\text { gjengelig } \\
\text { "Få folk i tale, } \\
\text { fange opp me- } \\
\text { ninger der ute" }\end{array}$ & $\begin{array}{l}\begin{array}{l}\text { Rett fra levra } \\
\text { (spontan) }\end{array} \\
\text { Profilering med } \\
\text { kontroll: Legger } \\
\text { premisser for } \\
\text { debatt } \\
\text { Åpner for mer } \\
\text { personfoku- } \\
\text { sering: "Et langt } \\
\text { steg nærmere } \\
\text { velgerne" }\end{array}$ & $\begin{array}{l}\text { Kort, muntlig } \\
\text { og personlig } \\
\text { dagbokstil uten } \\
\text { hengelås }\end{array}$ & $\begin{array}{l}\text { Interaktiv: Fra } \\
\text { Halvorsen til } \\
\text { velgerne, } \\
\text { fra velgerne til } \\
\text { Halvorsen, } \\
\text { fra velgere til } \\
\text { velgere } \\
\text { Halvorsen sva- } \\
\text { rer sjelden på } \\
\text { bloggdeltakeres } \\
\text { innspill }\end{array}$ & $\begin{array}{l}\text { Meningsbasert } \\
\text { (i alle fall for } \\
\text { menn) } \\
\text { Etter den første } \\
\text { begeistringen en } \\
\text { stadig sterkere } \\
\text { kritikk av man- } \\
\text { glende postin- } \\
\text { ger/respons fra } \\
\text { Halvorsen }\end{array}$ & $\begin{array}{l}\text { N=549 blogg- } \\
\text { kommentarer } \\
\text { på } 44 \text { postinger } \\
\text { Menn: } 72 \% \\
\text { Kvinner: } 12 \% \\
\text { IOK*: } 16 \%\end{array}$ \\
\hline $\begin{array}{l}\text { Nett- } \\
\text { møter }\end{array}$ & $\begin{array}{l}\text { "Få folk i tale, } \\
\text { fange opp me- } \\
\text { ninger der ute" } \\
\text { Gi personlige } \\
\text { svar }\end{array}$ & $\begin{array}{l}\text { Rett i øret (lyt- } \\
\text { tende) } \\
\text { Profilering med } \\
\text { liten kontroll: } \\
\text { Nettmøtedel- } \\
\text { takerne legger } \\
\text { premissene } \\
\text { Responde- } \\
\text { rende, følelses- } \\
\text { orientert, } \\
\text { tydelig, nær og } \\
\text { varm }\end{array}$ & $\begin{array}{l}\text { "Lytter" med } \\
\text { fingertupper og } \\
\text { tastatur } \\
\text { Korte, muntlige } \\
\text { og personlige } \\
\text { svar }\end{array}$ & $\begin{array}{l}\text { Interaktiv: } \\
\text { Fra velgerne til } \\
\text { Halvorsen, svar } \\
\text { fra Halvorsen } \\
\text { samme dag }\end{array}$ & 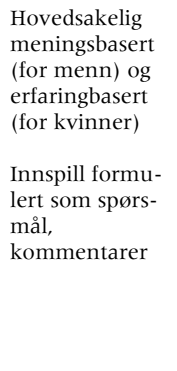 & $\begin{array}{l}\text { N=99 nettmøte- } \\
\text { spørsmål for- } \\
\text { delt på to nett- } \\
\text { møter } \\
\text { Menn: } 63 \% \\
\text { Kvinner: } 30 \% \\
\text { IOK*: } 7 \%\end{array}$ \\
\hline
\end{tabular}

* IOK = ikke oppgitt kjønn

I boka var Halvorsens mål å få folk til å gjenkjenne SV-eren i seg selv, å «bli med». Gjennom midtsceneprofilering «bød» hun på seg selv. I tråd med et norsk politisk offentlighetsideal, posisjonerte hun seg som antielitistisk, engasjert, folkelig og nær, ifølge enkelte kommentatorer for nær og privat. De menneskelige sidene var ikke ment å være et mål i seg selv, men å gjøre politikken mer intuitivt fattbar, og kanskje også mer interessant. Dette gjorde hun ved å fortelle litt om seg og sitt. Ifølge Aslak Bonde (Politisk analyse, 19.11.04) gjorde Halvorsen det til en dyd å føre en politikk som alle kunne «forstå til enhver tid». Det hadde med identifikasjon å gjøre. Uten journalistiske mellomledd, ga bokformen full kontroll over selvpresentasjonen gjennom mange og lange resonnementer. 
Norsk politisk lederskap forutsetter, som antydet, sosial nærhet til og identifikasjon med velgerne ( «jeg er lik dere»). Halvorsen er en av de politikerne som blant annet gjennom sitt bosted på Oslos østkant (selv om Grünerløkka ofte regnes som østkantens vestkant), også markerer en geografisk nærhet ( «jeg er blant dere/jeg bor her»). Hadde det ikke vært for sikkerhetsforanstaltninger, ville hun helst ha spasert til jobben hver dag. I denne artikkelen har jeg vist at Halvorsen også uttrykker samhørighet med velgerne gjennom boka si («jeg er en av dere»), en bok der politikere oppfordres til ikke å skille seg ut i forhold til «folk flest». Jeg mener dessuten å ha demonstrert at Halvorsen, i tillegg til de øvrige nærhetsmarkeringene, også har vist en helt konkret og personlig nærhet til velgerne gjennom blogg og nettmøter ("jeg er tilgjengelig»). ${ }^{18}$ Nettmedienes materiellstruktur åpnet dermed for ytterligere personfokusering, sammenliknet med boka - og andre medier. "Et langt skritt nærmere velgerne», ble det omtalt som i partiet. Disse endringene i kommunikasjonsmediene, som Meyrowitz' (1985) beskriver, kan dermed, i motsetning til Goffmans (1992) perspektiv, gjøre rede for hvordan sosiale roller og situasjoner struktureres og endres. Ifølge Meyrowitz vil nye medier forrykke forbindelsen mellom fysisk setting og sosial situasjon ved å føre ulike mennesker til det samme «stedet». I den grad Halvorsen fikk til dette, kunne hun tilrive seg en politisk merverdi i forhold til politikere med mindre scene og smalere nærhetsrepertoar å spille på.

Nettet ga dermed Halvorsen en ny dimensjon, en ny stemme. Som med bokforfatterstemmen, kunne heller ikke nettstemmen kuttes og omredigeres av andre. Men stemmen var ikke så formell som den var i bokform. Og i motsetning til boka, der kommunikasjonsretningen var fra én til mange, var blogg- og nettmøtekommunikasjonen to- og flerveis, kortere, hyppigere og mer muntlig. Halvorsens erklærte mål med blogg og nettmøter var å nå de som egentlig var interessert i politikk, men som kanskje ikke hadde særlig interesse for politikken slik den ofte ble fremstilt i andre medier. Gjennom bloggen fremsto Halvorsen som et vennlig, raust, kontant, impulsivt og sjarmerende menneske; et politisk menneske, men også et hverdagsmenneske - uten hengelås på dagboka. Kontrollen over selvpresentasjonen var likevel større i bloggen enn i den mer synkrone nettmøtekommunikasjonen.

Når det gjelder responsen på Halvorsens kombinerte bok/hjemmeside, var det bare enkelte av anmelderne, som hovedsakelig var menn, som så ut til å la seg begeistre. Mange var forbeholdne, noen regelrett avvisende. Når det gjelder bloggingen, må spørsmålet om Halvorsens gjennombruddskraft knyttes til ulike faser. Bloggstarten kom på - og skapte - en begeistringens bølge. Bloggkommentatorene betraktet henne som en som ikke bare supplerte, men fornyet deler av den politiske samtalen. Medlemmer i andre partier uttrykte misun- 
nelse, forbannelse og fortvilelse over SVs effektive profilering av egne (og andres) merkevarer, at SV hadde «en likandes partileder som i mangt og mye har frekkhetens nådegave" (http://www.liberal.no 26.11.04). Det ble hevdet at SV var i ferd med å ta over for Fremskrittspartiet når det gjaldt dyktig markedsføring. Da nyhetens interesse forsvant og Halvorsens bloggpostinger og nettmøter ble sjeldnere, var det kjeft, kritikk og kverulering som preget bloggkommentarene. Til tross for støtte fra enkelte, ble Halvorsen heftig kritisert for ikke å holde det hun tidligere hadde bundet seg til i sin statsrådsregel: «å la velgerne få vite hva hun hadde på hjertet, å sette av tid til å lese folks meninger og å svare på spørsmål.» Dette løftebruddet ble oppfattet som særdeles lite sjarmerende. Nettkarisma er dermed skjørt. Kanskje kan de nesten urealistiske forventningene om å komme nær en politiker resultere i at mottakerne utvikler en større bevissthet om forskjellene mellom den politiske eliten og dem selv (se Sørbø, 1991)?

Et stort spørsmål når det gjelder nedslagsfeltet er imidlertid hvor det ble av kvinnene. Boka, som i hovedsak var rettet mot kvinner - og antakelig mest lest av kvinner - ble i første rekke kommentert og diskutert av menn. Videre viser undersøkelsen at kvinnene deltok under halvparten så ofte som mennene i nettmøtene og i minimal grad i bloggen. Hadde SV vanskelig for å overskue hvordan nettmediets, og særlig bloggens teknologiske innretning kunne slå ut? Trodde man at eventuelle digitale kjønnsskiller var jevnet ut? I så fall bringer denne studien dårlige nyheter. Mennene satte dagsorden, var mer meningssterke og tok mer "plass» i kommunikasjonen enn kvinnene. Således kan SVs nettaktivisme sies å ha bekreftet - og kanskje for en stund forsterket - ulikheter i politisk deltakelse mellom kjønn. At det digitale kjønnsskillet var så overtydelig er egentlig pussig, siden disse politiske utspillene ble formulert av og gjennom en kvinne, en kvinne som attpå til sies å være en av de mest folkelige politikerne i Norge.

\section{Spør en politiker ...}

De færreste av oss er freidige nok til å gi Halvorsen en klem i køen til kassa på Rimi en gusten oktoberdag, slik en av nettdebattantene gjorde. Men valgåret før stortingsvalget i 2005 var året da vi alle kunne ta en liten nettprat med Halvorsen, gjerne en lørdags eller søndags morgen. Skriv til en politiker, og du blir lest. Spør en politiker, og du får svar, personlig svar, angivelig «rett fra levra». Norske politikere - og ikke minst venstresidens politikere, som kan vise til sterke tradisjoner for likhetsideologi - har mange stemmer å hente ved å snakke seriøst om egne hjertesaker samtidig som de presenterer seg som personlige og folkelige overfor mange og varierte velgergrupper. Men Halvorsen skaffet seg også et særpreg ved å være først ute med en, i norsk sammenheng, 
ny politisk øvelse: Hvem er mest personlig nett-tilgjengelig? Hun forsøkte med andre ord å konvertere den anerkjennelsen hun vanligvis tillegges i etablerte medier til hjemmeside, blogg og nettmøter.

Jeg har gjennom en kombinasjon av perspektivene til Weber, Goffman og Meyrowitz argumentert for at midtsceneprofilering er en dekkende betegnelse på den passelige miksen av politisk og personlig-sjarmerende iscenesettelse Halvorsen utviste i sin nettkommunikasjon. Nettet, der det i utgangspunktet er «no sense of place» (Meyrowitz, 1985), ble omgjort til et sted, en interaktiv scene, gjennom Halvorsens personlig-politiske kommunikasjon. Selv om det kom kritikk, er nok Halvorsen en av norsk politikks bedre utøvere i denne kombinertøvelsen, som innebærer kontrollerte utporsjoneringer fra bakscene til scene. Trass i at denne kommunikasjonen nødvendigvis er offentlig og formell, kom boka - angivelig - «rett fra hjertet», bloggen "rett fra levra» mens nettkommentarene gikk "rett i Halvorsens øre». Gjennom disse tre valgkampstrategiske virkemidlene posisjonerte Halvorsen seg som en arlig, spontan og lyttende politisk leder.

Konklusjonen er videre at nettkommunikasjonen var ny, interessant og oppmerksomhetsskapende i første del av den lange valgkampen frem mot valget i 2005. Halvorsen baserte seg på delvis nye forteller- og kommunikasjonsmåter sammenliknet med tidligere politisk kommunikasjon, kommunikasjonsmåter som lå på siden av de etablerte arenaene som politiske partier og organisasjoner vanligvis benytter. Nettkommunikasjonen ble imidlertid en lite bærekraftig aktivitet for Halvorsen frem mot den mer intense delen av samme valgkamp. Det å snakke med og ikke bare til folk, kostet åpenbart mye - når det gjaldt tid, innsats og inntrykkskontroll. Man kan også spørre seg om det personlige bloggformatet egentlig passer for svært opptatte mennesker. Under valgkampen i 2001 fortalte Halvorsen at valgkampen var blitt et spørsmål om ren kondis. Hun savnet joggedressen (Krogstad, 2004b:212). Siste del av valgkampen i 2005 var ikke mindre travel. Halvorsen opptrådte i alle kanaler, men altså ikke lenger på egen blogg. Selv om hun faktisk kunne ha blogget i joggedress.

Halvorsens nedlegging av bloggen kan ikke bare forklares med tidspress og personlig press. Dersom hun og partiet virkelig hadde trodd at de nådde ut til et stort potensielt publikum, at de kunne få folk til å «finne SV-eren i seg» gjennom dette virkemiddelet, hadde de vel satset enda sterkere. Spørsmålet er også hvorvidt blogging er en god prioritering for en som allerede er relativt synlig i offentligheten. Kan - og bør - en partileder bruke sin verdifulle tid til å delta i dialog med uklart posisjonerte enkeltpersoner? Når SV - til tross for egeninteresse, ideologi og ressurser - ikke lyktes med sin eksterne nettsatsing, sier det kanskje noe mer allment om begrensningene i e-demokratiets muligheter? På 


\section{den andre siden er det ikke utenkelig at nettet i stadig større grad vil overta som viktig arena for politisk kommunikasjon. I så fall vil flere toppolitikeres priorite- ringer antakelig skifte.}

\section{Noter}

1 Jeg vil takke Svein S. Andersen, Anders Ekeland, Arvid Fennefoss, Marika Lüders, Jo Saglie, Aagoth Storvik og tidsskriftets to anonyme konsulenter for kommentarer til artikkelen. Hovedinformant Tom Nørbech i SV har også lest og kommentert flere versjoner av artikkelen. Takk!

2 Ifølge Computerworld (01.12.04) var det bloggere som først stilte spørsmål ved dokumenter som skulle bevise at George W. Bush snek seg unna militærtjenesten. Det var også bloggere som ga støtet til spekulasjonene om at Bush hadde et skjult apparat under dressjakken for å motta meldinger under den første debatten mot John Kerry i valgkampen 2004. Videre er det mange som krediterer bloggere for å ha presset Trent Lott, det amerikanske senatets majoritetsleder, til å gå av etter å ha kommet med noen famøse uttalelser i Strom Thurmonds 100-årsdag i 2002 (Drezner og Farrell, 2004).

3 http://www.nesteklikk.no/norskbloggen/index.html, 03.03.05.

4 Blogging har også trengt gjennom i de etablerte mediene i Norge: Alle de store avisene (Dagbladet, $V G$ og Aftenposten) og flere mindre har lansert egne blogger, der også politikere inviteres med.

5 Sistnevnte intervjuer er foretatt sammen med Jo Saglie (ISF) og Anders Ekeland (NIFU-STEP).

6 Dette ser man blant annet ved at personvinklingen har økt kontinuerlig sidene valgene på 1950-tallet og frem til i dag (Sandnes, 2004).

7 Halvorsen var riktignok ikke den første norske politiker med egen blogg. Først ute var tidligere fylkesordfører i Finmark (Ap), senere fiskeriminister Helga Pedersen (hennes blogg er riktignok nedlagt). Den andre som startet med blogging var Unge Høyres leder, Torbjørn Røe Isaksen, som startet ca. en måned tidligere enn Halvorsen (http://www.ungehoyre.no). Han har imidlertid blitt kritisert for ikke å være en ekte blogger, siden hans blogg ikke gir mulighet for kommentarer. Etter Halvorsen, som dermed var nummer tre i rekken, startet Unge Venstres leder, Lars-Henrik Michelsen, sin egen blogg 2. februar 2005 (http://www.ungevenstre.no). Denne inkluderte fra 1. mars 2005 en ny form for blogging på nettet, videoblogging, eller "vlogging", som det også kalles. Unge Venstre er dermed det første ungdomspartiet i verden som tar i bruk videoblogging.

8 Trippi tilbød SV en egen nettløsning til gratis bruk i valgkampen 2005, raust anslått til en verdi av nærmere 1,6 millioner dollar (jf. intervju med Nørbech, 12.11.04).

9 Leder i Ukeavisen Ledelse (nr. 28, 19.08.05).

10 http://www.nesteklikk.no/norskbloggen/index.html

11 Intervju med Nørbech, 12.11.04.

12 http://www.voxpolitics.com/weblog/archives/00310.htlm 13 Intervju med Nørbech, 12.11.04.

14 http://www.ungehoyre.no

15 Intervju med Høyres organisasjons- og kampanjesjef Nordan Helland og IT-sjef Thomas Berg Olsen, 16.2.05.

16 http://www.nesteklikk.no/norskbloggen/index.html

17 Det at Halvorsens blogg ble nedlagt trekvart år etter oppstart, kan selvsagt tas til inntekt for at det hele var mislykket, en flopp. Men må en blogg bestå over lang tid for å bli kalt vellykket? Kan et kort, høyintensivt valgkampstunt også gi mening?

18 Takk til Jean-Pascal Daloz for interessante innspill om politikeres nærhetsretorikk i hans forelesning ved Institutt for statsvitenskap, Universitetet i Oslo, 28.03.07, samt i personlig kommunikasjon. 
Coleman, S. (2001) Cyber Space Odyssey. The Internet in the UK election. www.hansardsociety.org.uk

Daloz, J.-P. (2007) 'Political Elites and Conspicuous Modesty: Norway, Sweden, Finland in Comparative Perspective', i F. Engelstad og T. Gulbrandsen (red) Comparative Studies of Social and Political Elites. Comparative Social Research 23 (s. 171-210). New York, Oxford: Elsevier Jai.

Drezner, D. W. og Farrell, H. (2004), ' The Power and Politics of Blogs'. Paper presented at the 2004 American Political Science Association.

Eide, M. (2001) Til dagsorden! Journalistikk, makt og demokrati. Oslo: Gyldendal Akademisk.

Gibson, R., Margolis, M., Resnick, D. og Ward, S.J. (2003) ' Election Campaigning on the WWW in the USA and UK: A Comparative Analysis', Party Politics 9:47-75.

Goffman, E. (1992 [1959]) Vårt rollespill til daglig. En studie i hverdagslivets dramatikk. Oslo: Pax Forlag A/S.

Goffman, E. (1963) Behavior in Public Places. Notes on the Social Organization of Gatherings. New York: The Free Press.

Gripsrud, J. (2002) Mediekultur, mediesamfunn. Oslo: Universitetsforlaget.

Grönlund, K. (2004) ' Cyber Citizens: Mapping Internet Access and Digital Divides in Western Europe', i N. Kersting og H. Baldersheim (red) Electronic Voting and Democracy: A Comparative Analysis. Basingstoke: Palgrave Macmillan.

Halvorsen, K. (2004) Rett fra hjertet. Oslo: Gyldendal.

Heidar, K. og Saglie, J. (2002) Hva skjer med partiene?. Oslo: Gyldendal Akademisk.

Henningsen, E. og Vike, H. (1999) 'Folkelig elitisme? Om offentlighetens kultur i Norge', Norsk antropologisk tidsskrift 10:150-167.

Hestvik, H. (2004) 'valgkamp2001.no'. Partier, velgere og nye medier. Ny kommunikasjon? ' i B. Aardal, A. Krogstad og H. M. Narud (red) I valgkampens hete (s. 230-251). Oslo: Universitetsforlaget.

Karlsen, R., Aardal, B. og Christensen, B. A. (2005) 'Elektronisk stemmegivning. De første norske erfaringer', i J. Saglie og T. Bjørklund (red) Lokalvalg og lokalt folkestyre (s. 122-141). Oslo: Gyldendal Akademisk.
Krogstad, A. (1999) Image i politikken. Oslo: Pax forlag AS. Krogstad, A. (2004a), 'Fjernsynsvalgkamp. Noen retoriske øvelser i fordeling av skyld og ære', i B. Aardal, A. Krogstad og H. M. Narud (red) I valgkampens hete (s. 85-111). Oslo: Universitetsforlaget.

Krogstad, A. (2004b), ' 'En joggedress og en gråpapirpose over hodet, takk.' Valgkamp og terningkast', i B. Aardal, A. Krogstad og H. M. Narud (red) I valgkampens hete (s. 203-229). Oslo: Universitetsforlaget.

Krogstad, A. og Storvik, Aa. (2007) 'Seductive Heroes and Ordinary Human Beings: Charismatic Political Leadership in France and Norway', i F. Engelstad og T. Gulbrandsen (red) Comparative Studies of Social and Political Elites. Comparative Social Research 23 (s. 213245). New York, Oxford: Elsevier Jai.

Kummervold, P. E. (1998) Stedløse samfunn: sosial organisasjon og kommunikasjon på Internet Relay Chat. Hovedfagsoppgave. Tromsø: Universitetet i Tromsø.

Lien, M., Vike, H. og Lidén H. (2001) Likhetens paradokser. Antropologiske undersøkelser $i$ det moderne Norge. Oslo: Universitetsforlaget.

Löfgren, K. (2001) Political Parties and Democracy in the Information Age - The Case of Denmark and Sweden. Ph.d.-avhandling. København: Institutt for Statskundskab, Københavns Universitet.

Meyrowitz, J. (1985) No Sense of Place. The Impact of Electronic Media on Social Behavior. New York: Oxford University Press.

Mortensen, T. og Walker, J. M. (2002) ' Blogging Thoughts: Personal Publication as an Online Research Too'l, i A. Morrison (red) Researching ICTs in Context (s. 249-279). Oslo: Intermedia, Universitetet i Oslo.

Norris, P. (2001) Digital Divide: Civic Engagement, Informations Poverty and the Internet Worldwide. New York: Cambridge University Press.

Nørbech, T. (2002) Prosjektplan SVisj-vev. Utnyttelse av interaktive løsninger. Sosialistisk Venstreparti.

Pedersen, K. og Saglie, J. (2005) 'New Technology in Ageing Parties: Internet Use in Danish and Norwegian Parties', Party Politics 11:359-77.

Rasmussen, T. (2003a), ' Media of the Self. Reflections on the personal web page'. (www.media.uio.no/personer/terjer). 
Rasmussen, T. (2003b). 'Masken foran masken. E. Goffman og personlig presentasjon på web'. Upublisert nettmanus. Institutt for medier og kommunikasjon, Universitetet i Oslo. (www.media.uio.no/ personer/terjer).

Rheingold, H. (1993) The Virtual Community. Homesteading on the Electronic Frontier. Addison-Wesley. Revised edition 2000 Cambridge, Mass.: MIT Press. http:/ /www.rheingold.com/vc/book/

Saglie, J. (2007) ' Massepartier i cyberspace? Om bruk av IKT i norske partier', Norsk statsvitenskapelig tidsskrift 23:123-147.

Saglie, J. og Vabo, S. I. (2005) 'Elektronisk politisk deltakelse - en aktivitet for de få? ', i J. Saglie og

\section{Aviser, magasiner}

Computerworld, 01.12.04.

Dagbladet, 11.10.2004.

Dagbladet, 27.12.05.

Dagens Naringsliv, 20./21.11.04.

Dagsavisen, 29.10.04.

Kvinner og klar, leder av Bente E. Engesland, 19.04.05. Magasinet Aktuell, Ole Kr. Mortensen, 15.11.04.

Morgenbladet, Trond Berg Eriksen, 26.11.2004.

Morgenbladet, Hanne Andrea Kraugerud, 29.11.04.

\section{Webadresser}

http://www.liberal.no, lesedato 26.11.04.

http://www.nesteklikk.no/norskbloggen/index.html, lesedato 03.03.05.

http://sf.blogs.com/holger_k, lesedato 06.02.05.

http://www.svkristin.no, lesedato 15.03.05.
T. Bjørklund (red) Lokalvalg og lokalt folkestyre (s. 161-177). Oslo: Gyldendal Akademisk.

Sandnes, M. (2004) Det personlige vinklingspress. En innholdsanalyse av norske og svenske avisers dekning av politiske valgkamper $i$ tidsrommet 1953-1998. Hovedoppgave. Bergen: Institutt for sammenliknende politikk, Universitetet i Bergen.

Sørbø, J. I. (1991) Offentlig samtale. Innføring i presseetiske grunnspørsmål. Oslo: Det Norske Samlaget.

Weber, M. (1968 [1922)) Economy and Society, an Outline of Interpretive Sociology. Redigert av Guenther Roth og Claus Wittich. New York: The Bedminster Press.

Ny Tid, Anders Horn, 30.10.04.

Ny Tid, Anders Horn, 01.11.04.

Observer Norge/Mandag Morgen, 22.08.05.

Politisk analyse, Aslak Bonde, 19.11.2004.

Sakprosa, Jørgen Haavardsholm, 28.09.04.

Stavanger Aftenblad, sjefredaktør Tom Hetland,

11.11.04.

Ukeavisen Ledelse, leder i nr. 28, 19.08.05.

$V G$, Arve Øverbø, 08.12.04.

http://www.ungehoyre.no, lesedato 20.03.05.

http://www.ungevenstre.no, lesedato 1.04.05.

http://www.voxpolitics.com/weblog/archives/00310.htlm,

lesedato, 04.03.05.

http://carlbildt.wordpress.com, lesedato 08.03.07. 